RUIZ, Manuel: “La arquitectura penitenciaria como representación del castigo. Las maneras de comprender la pena de prisión en la historia".

Polít. Crim. Vol. 15, No 29 (Julio 2020), Art. 15, pp. 406-451

[http://politcrim.com/wp-content/uploads/2020/07/Vol15N29A15.pdf]

\title{
La arquitectura penitenciaria como representación del castigo. Las maneras de comprender la pena de prisión en la historia*
}

\section{Penitentiary architecture as a representation of punishment. Different ways to understand prison sentence in history}

\author{
Manuel L. Ruiz-Morales \\ Personal docente e investigador de la Universidad de Cádiz (España) \\ manuel.ruizmoral@uca.es
}

\section{Resumen}

El presente artículo analiza la evolución de la arquitectura penitenciaria, a partir de la noción de castigo desarrollada e implantada en determinado momento histórico. Igualmente, demuestra cómo la alteración en el entendimiento del castigo, en su finalidad y pretensión, afecta al diseño y a las infraestructuras de las cárceles del mundo. Por ello, el presente estudio realiza un recorrido desde la Antigüedad hasta nuestros días por la disciplina penal y penitenciaria de la institución carcelaria, examinando los diversos diseños penitenciarios que existieron desde las primeras civilizaciones hasta la instauración del Derecho Penal en el sentido moderno, ya que éste fue el hecho que terminó por investir a la pena de prisión de una relevancia que no ostentó hasta dicho momento, convirtiéndose a partir del siglo XIX en el castigo principal del catálogo de sanciones penales con las que contaba el Estado. En la actualidad, la cárcel sigue manteniendo ese papel protagonista en el sistema penal, no obstante, ha venido surgiendo - en el último siglo- unos modelos carcelarios divergentes y contrapuestos en su filosofía y pretensión, dando lugar a las prisiones hijas de la resocialización - por un lado - y las cárceles hijas de las sociedades de control — por otro lado-.

Palabras clave: prisión, arquitectura penitenciaria, comprensión, castigo, evolución

\begin{abstract}
This article analyses the penitentiary architecture evolution, based on the notion of punishment deployed in a particular historical period. In this sense, it is described how the alteration on the understanding and on the underlying purpose of the chastisement, affects the designs and facilities of the prisons around the world. This study conducts a review throughout the prison history from antique times to our days through theories of criminal law. In this historical review it will be observed how the imprisonment became the mayor way of punishment as of nineteenth century. Today, the prison still remain in force in the penal system, nevertheless, two different prison models have emerged in the
\end{abstract}

\footnotetext{
* Investigación desarrollada gracias a la financiación del Plan Propio de la Universidad de Cádiz (2017). Trabajo expuesto parcialmente mediante ponencia en las II Jornadas de Estudios Penitenciarios "Horizontes historiográficos de los estudios penitenciarios. Nuevos enfoques, herramientas y convergencias teóricas", bajo el título "El castigo en prisión. La cárcel como resultado del entendimiento del castigo". Lugar de celebración: San Miguel de Tucumán (Argentina). 26-27 de octubre de 2017. Actividad organizada por la Universidad Nacional de Tucumán, el Instituto de Investigaciones Históricas Dr. Ramón Leoni Pinto, la Fundación Miguel Lillo, la Honorable Legislatura de Tucumán y la Fundación Argentina de Estudios en Derecho, Historia y Política.
} 
last century: on one side, the re-socialising prisons and, on the other side, the fully vigilant prisons.

Keywords: prison, penitentiary architecture, understanding, punishment, evolution.

\section{Nociones previas}

Hace unas casi cuatro décadas, Umberto Eco declaró “es posible que la arquitectura se funde en los códigos arquitectónicos existentes, pero en realidad se ha de apoyar plenamente en otros códigos que no son suyos". ${ }^{1}$

Esta afirmación dejaba bien a las claras la pretensión sobre la que se asienta el presente artículo. La arquitectura necesita basarse en la funcionalidad, intencionalidad y significación del edificio que se desea proyectar. Ello determinará cierta representación del mismo, en cuanto a su imagen exterior, e incluso, en algunos casos, emitirá un cierto mensaje al observador de la edificación.

Por tanto, el estudio de la arquitectura penitenciaria no debe realizarse atendiendo a fundamentos arquitectónicos elementales y propios de esa disciplina, sino desde la óptica teórica y el entendimiento concreto de la finalidad que debe cumplir la estructura edilicia.

Es por eso que castigo y prisión son dos conceptos que, desde hace algo más de dos siglos, van de la mano. El segundo siguiendo al primero, hasta el punto de que la propia arquitectura, puede dilapidar todo el sistema jurídico penal, si no existe una efectiva concordancia entre esas dos primigenias nociones, o lo que es lo mismo, entre la construcción y su propósito. ${ }^{2}$

Aunque esto parece conforme y/o aplicable a toda la ciencia arquitectónica en general, es especialmente relevante en relación al edificio dedicado al encierro de personas, debido a las peculiaridades de mencionada pretensión, que puede llevar a replantear la naturaleza de la edificación si no aparece esa adecuada asonancia. ${ }^{3}$

Lo que se viene argumentando ostenta tanta veracidad, que en las postrimerías del siglo XIX, el distinguido criminólogo español Rafael Salillas ya decía que "todas las reformas

\footnotetext{
${ }^{1}$ ECO (1978), p. 375.

${ }^{2}$ Esta armonía entre castigo y prisión, y la evolución que ha ido sufriendo la arquitectura penitenciaria, se ha venido extendiendo por todos los países del mundo, por lo que el trabajo se detendrá en las prisiones más prototípicas y vanguardistas de cada tipología. En este sentido, es dable destacar cómo, por ejemplo, en el particular argentino se ha trabajado y analizado el paso en su arquitectura penitenciaria desde edificios carcelarios surgidos como dependencias de edificios más grandes — como cabildos - a los complejos penitenciarios - como el de Ezeiza - - pasando por los primeros edificios carcelarios independientes - caso de Paraná en 1831 o Concepción de Uruguay en 1836-, el partido claustral o "conventual" -como el de Gualeguaychú de 1890-, los “panóticos” o pseudo-panópticos, el partido radial o en estrella -que llegó a Argentina a través de Chile y se instauró en la Prisión de Mendoza de 1865-, el partido pabellonar-como la cárcel de Paraná de 1883- y el paralelo -como la Cárcel de Tucumán de 1922-, así como las penitenciarías y complejos, siguiendo el mismo transcurrir que el resto de los países del mundo -en mayor o menor medida-. Véase, GARCÍA BASALO y MITHIEUX (2017), pp. 29-39.

${ }^{3}$ Tanto es así que el diseño de la prisión puede afectar no al castigo y sus formas, sino también a la manera de relacionarse los reclusos y los funcionarios de prisiones. Véase, BEIJERSBERGEN et al. (2014), pp. 844-845.
} 
jurídicas [serían] inútiles, ociosas y vanas, mientras no se [promoviese] una gran reforma en la arquitectura penal". ${ }^{4}$

\section{1. Definiciones preliminares}

En primer lugar, es dable destacar que el vocablo "cárcel"5 procede etimológicamente del término romano: "carcer" , que se utilizaba para referirse al "espacio donde se retienen bajo custodia los elementos que allí se guardan". ${ }^{7}$ No obstante, no era la única palabra que apuntaba a la realidad carcelaria y al encarcelamiento, sino que existían otras como el término "custodia" - que aunque ostenta diferentes acepciones, una de ellas se refería a la designación del lugar, al individuo y a la forma de encarcelamiento-, o el de "vincula" - que a pesar de aludir a los lazos, las ataduras y las cadenas que unen a las personas entre sí; a menudo se usaba como sinónimo del término "carcer" —.

Más tarde, en torno a la Edad Media, surgen ya nuevos conceptos y términos, que se usan para designar a esta misma realidad. Es el caso de "presidio" - expresión anticuada que gramaticalmente se refería a la guarnición de soldados que se ponían en las plazas, castillos y fortalezas para su custodia y defensa, así como también a la ciudad o fortaleza que se puede guarnecer de soldados-, o de penitenciaría - que designaba al lugar solitario y apartado del ruido cortesano al que debían recurrir los penitentes religiosos para aislarse dentro de su mundo interior, introspectivamente, a efectos de lograr el arrepentimient-.

\section{2. Unas notas en torno al castigo ${ }^{8}$}

Antes de entrar en el fondo del trabajo, sería lógico preguntarse por qué es menester que exista un lugar para ejecutar el encierro, esto es, cuál es la razón de su creación. Para contestar esta pregunta se debe abordar y dilucidar cuestiones del estilo de las que siguen: ¿Qué es el castigo? ¿Para qué sirve el mismo?

Pues bien, para obtener una primera aproximación sobre lo que es el castigo, nada mejor que acudir a la Real Academia Española (RAE), la cual nos lo define como "pena que se impone a quien ha cometido un delito o falta". Por lo que, con dicha noción inmediatamente se liga este concepto con el Derecho Penal, aunque tampoco es menos cierto que se vinculan y hacen equivalentes en el concepto del propio diccionario las acepciones tanto de castigo como de pena.

Mas la concepción que se ha dado sin ser fútil, tampoco es que sea demasiado prolija, por ello es menester analizar lo que sería exactamente el "castigo" para las ciencias jurídicas. Así, para algunos juristas "el castigo tiene que ser un mal o algo no placentero para la víctima del mismo, infligido con motivo de una ofensa, a la persona que se supone

\footnotetext{
${ }^{4}$ SALILLAS (1888), p. 22.

5 A la hora de referirnos a la prisión, habitualmente se utiliza el término "cárcel", que responde a dos significados diversos. De un lado, hace referencia a la propia pena privativa de libertad, y de otro, se refiere al edificio establecido para el cumplimiento de estas penas.

${ }^{6}$ Otros autores indican que el término "carcer" posee un origen hebreo, y significaba cadena.

${ }^{7}$ CASTRO (2007), pp. 29-32.

${ }^{8}$ Habría que tener en cuenta que el castigo es una "institución total compleja", que no puede estudiarse aisladamente, sino que necesariamente hay que analizarlo en su totalidad, debido a la gran interrelación de los fenómenos sociales. Véase, GARLAND (2006), p. 332.
} 
ofensor, en virtud de una autoridad conferida por las instituciones en contra de cuyas normas ha sido cometida la ofensa". ${ }^{9}$

Posteriormente, otros autores añadieron, a esta noción inicial, que ese displacer debía ser parte esencial de lo propuesto y no algo incidental. Igualmente, con el paso del tiempo se entendió que la ofensa que daba origen al castigo debía ser contra las normas jurídicas, siendo a su vez necesario que dicho castigo fuera impuesto por alguien distinto al ofendido. ${ }^{10}$

Ahora bien, el tratamiento jurídico del castigo no se abordó únicamente desde el ámbito de la dogmática jurídico penal, sino que entraron en juego otras ciencias autónomas pero vinculadas o relacionadas a la misma, como ocurre con la criminología.

De este modo, para la ciencia que estudia y analiza el crimen el delincuente es un sujeto con anomalías, y consecuentemente, alguien susceptible de un tratamiento, esto es, susceptible de intervención. Por tanto, la sanción social como intervención a la que se somete al individuo victimario intenta perseguir la eficacia preventiva y la protección social frente a delitos futuros. La intervención, en cuanto modalidad de sanción, se determinará en juicio por parte de un tribunal, una vez se cometió el delito y, asimismo, se controlará jurídicamente su ejecución, lo que supondrá el respeto - durante su realización y cumplimiento - de los derechos del penado. ${ }^{11}$ Por ello, es hoy día básico atender a la personalidad del sujeto delincuente, a sus necesidades tratamentales, sus actitudes, etc. a la hora de adjudicar el tipo de intervención individual a emplear. No obstante, el derecho a no ser readaptado se presenta en principio tan legítimo como los de libre pensamiento y autodeterminación reconocidos a nivel nacional e internacional en constituciones y tratados internacionales. ${ }^{12}$

Incluso a veces - a título de mera curiosidad - el castigo es anticipado al hecho delictivo, como es el caso de las medidas de seguridad pre-delictuales, en base a criterios puramente subjetivos - como son la sospecha de haber cometido delitos, o la simple peligrosidad del sujeto derivada de condiciones personales - ${ }^{13}$ Por lo que se castiga no quia prohibitium, sino quia peccatum y, por ende, no tanto por lo que se ha hecho, sino por lo que se es. ${ }^{14}$

\section{Las primeras formas de hacer justicia y los modos de castigar}

\section{1. La autotutela}

La forma más elemental y primigenia de hacer justicia consistió en la venganza individual y privada, esto es, lo que se denominado autotutela.

Este es el punto en el que muchos de los filósofos de la historia fijaban el inicio de sus discursos filosóficos, puesto que se iniciaban las tesis en base a las ideas en torno a la situación del hombre en estado de naturaleza.

\footnotetext{
${ }^{9}$ FLEW (1954), p. 299.

${ }^{10}$ FALCÓN Y TELLA y FALCÓN Y TELLA (2005), p. 22.

${ }^{11}$ FALCÓN Y TELLA y FALCÓN Y TELLA (2005) p. 35-36.

${ }^{12}$ MUÑAGORRI LAGUÍA (1977), pp. 178-179.

${ }^{13}$ Status de vago, vagabundo, proclive a delinquir, reincidente, delincuente habitual, etc.

${ }^{14}$ FERRAJOLI (1998), p. 42.
} 
En esta fase primigenia del deambular prehistórico del ser humano, el hombre se movía tras sus deseos o pasiones, los cuales ansiaba satisfacer para conseguir su felicidad. ${ }^{15}$ Por ejemplo, Hobbes explicaba que, en ese primer estadio, no existían los conceptos de justicia o criminalidad, ya que originalmente el individuo tenía derecho a todo, hasta el punto de servirse del propio cuerpo de los demás sujetos, lo que provocaba una seguridad nimia, una desconfianza general y un miedo mutuo. Por tanto, el hombre en estado de naturaleza se hallaba en una situación de "guerra de todos contra todos", ${ }^{16}$ en la que el débil se situaba en una posición muy desventajosa y sólo podía desquitarse del fuerte, cuando éste se encontraba desprevenido y desvalido.

Un ejemplo paradigmático de la autotutela era la Ley del Talión o Lex Talionis, ${ }^{17}$ que se encontraba establecida en algunos pasajes del código babilónico de Hammurabi o en algunos pasajes bíblicos — donde se desarrolla de la manera más diáfana, al enunciarlo como el "ojo por ojo, diente por diente" —. ${ }^{18}$

Sin embargo, ante la desconfianza que emanaba de este tipo de sistema, se fue articulando un castigo de carácter público en un acto de "todos contra todos" hasta que se hizo desaparecer a una de las partes contendientes.

Mas el sistema se fue morigerando, mesurándose hacia otros tipos de castigo sobre el individuo, tales como la esclavitud o el destierro. De este modo, se fue instituyendo el proceso de individualización de la pena, donde para castigar al culpable se entendía que lo mejor era aprehenderlo físicamente, a efectos de mitigar la posible fuga mientras se sustanciaba el juicio, consistiendo entonces el encierro simplemente en un medio de retención.

De ahí que desde el mundo prerromano hasta bien entrada la Edad Media, las cárceles fueran consideradas simplemente como lugares de detención para mantener al sujeto vigilado e inmovilizado a la espera de la resolución judicial de absolución o condena, esto es, para custodiar al individuo el tiempo hasta que transcurría el fatal devenir al modo de muerte, suplicio, o cualquier otra pena - como el destierro-, según las particularidades del lugar, de la civilización en cuestión y de la cultura de la misma. ${ }^{19}$

\section{2. La preponderancia de las penas corporales}

Posteriormente, desde el Medievo en adelante, comenzó a aparecer como una especie de derecho del soberano a hacer la guerra a sus enemigos. Pues bien, de esta manera, el castigo a los delincuentes fue como una de las varias dimensiones que ostentó ese derecho a castigar, que, en esta vertiente, consistía en procurar una venganza que era a la vez personal y pública, ya que la ley respaldaba la fuerza que imponía física-políticamente el soberano, ${ }^{20}$ en virtud de ese derecho sobre la vida y la muerte de sus súbditos que detentaba el monarca.

\footnotetext{
${ }^{15}$ RAMÍREZ (2011), pp. 22-25.

${ }^{16}$ GINZBURG (2015), pp. 30-49, p. 33.

${ }^{17}$ De talis, es decir, idéntico o semejante.

${ }^{18}$ Éxodo 21:24.

${ }^{19}$ CASTRO (2007), pp. 29-35.

${ }^{20}$ FOUCAULT (1990), pp. 53-54.
} 
Todo lo que se viene comentando fue consecuencia del ambiente punitivo que predominó hasta el siglo XVIII, que se puede resumir de forma loable utilizando las siguientes palabras de Tomás y Valiente: durante esta época "el repertorio de las penas legales era muy escaso en cuanto a las leves y muy amplio respecto a las de mayor dureza". Además, la pena de muerte "era muy frecuentemente establecida, a fin de aterrorizar eficazmente a los ciudadanos, reservando las formas más dolorosas para los delitos más graves". A mayor abundamiento, ocurría que "la gran cantidad de delitos castigados con la pena de muerte eliminaba toda posible proporcionalidad entre delitos y penas. [...] Además, la pena era principalmente el castigo merecido por el delincuente, y su imposición tenía muchos visos de una Justa Venganza, siendo utilizada por el legislador como arma represiva". ${ }^{21}$

De acuerdo a lo anterior, el castigo en esta época tenía como objetivo el cuerpo del reo, y en él se ensañaba, ya que la destrucción del mismo venía como a restituir el derecho del soberano -al que se hizo referencia anteriormente-, que había sido mancillado por la desobediencia que es todo delito. ${ }^{22}$ Era por eso que el castigo perseguía el cuerpo del reo más allá de la vida, incluso cuando ya había sobrevenido la muerte. Este era el período en el que el castigo asumió la forma de suplicio, equivalente al castigo sobre el cuerpo, donde el dolor no era complemento de la pena, sino la pena misma. En realidad, la finalidad de la tortura no era disimular la condena ni restablecer la justicia; era reactivar el poder. Por eso necesitaba de una ceremonia en la cual la publicidad del ritual manifestase su sobrepoder. ${ }^{23}$

La exposición o muestra del poder del monarca a la vista de todos los ciudadanos, no sólo restauraba - en cierto modo - la soberanía ultrajada por un momento; sino que además, con mencionada exhibición, lo que se pretendía era conceder a los hechos un valor disuasorio, ya que de esta manera se aterrorizaba a la población sometida, y se les alejaba de la posibilidad de que pudiesen o quisiesen delinquir en un futuro ante tan cruel amenaza. $^{24}$

Además, cabe mencionar que en aquella época del feudalismo más curtido, no era suficiente con el horror de la muerte, sino que era preciso comunicar más elementos al pueblo expectante. Para lograr este objetivo, se acompañaba la ejecución pública de un velo teatral, a efectos de que dicho aparato dantesco actuara sobre la imaginación de los presentes, sensibilizando a los habitantes, y convirtiéndolo en cómplice del brutal desenlace.

Por otra parte, en relación a la arquitectura penitenciaria y a la funcionalidad cumplida por aquellas estructuras edilicias, se debe comentar que en la Edad Media fue el momento

\footnotetext{
${ }^{21}$ TOMÁS Y VALIENTE (1973), pp. 185-187.

${ }^{22}$ FRAILE (1987), p. 14.

${ }^{23}$ FOUCAULT (1990), p. 62.

${ }^{24}$ No obstante, esta conclusión no se cumplía estrictamente, ya que era la ley la que permitía tal situación, toda vez que el mayor rigor punitivo provocaba que para mayor seguridad del delincuente, se cometieran más delitos, ya que si se imponía para casi todos los delitos la misma pena, esto es, se castigaban de igual manera, con pena de muerte un robo y un homicidio, no habría ningún delito menor que no viniese acompañado del más grave - es decir, no se cometerían robos sin asesinatos-. Obviamente, era sensato y racional ejecutar el segundo delito, puesto que éste permitía encubrir el primero, por lo que se ofrecía una ventaja, un incentivo al delincuente que realizaba las dos acciones antijurídicas. Véase FRAILE (1987), p. 14.
} 
histórico en el que apareció la prisión como pena, aunque únicamente en el marco del derecho canónico, destinada a los clérigos infractores de reglas eclesiásticas, así como para los herejes y delincuentes juzgados por la jurisdicción canónica, con el objetivo de obtener el arrepentimiento del culpable por medio de esta penitencia. ${ }^{25}$

No obstante, en el seno del derecho laico la cárcel no se utilizaba como pena, sino que seguía usándose como medio de aseguramiento y retención del delincuente hasta que se le impusiera la pena como condenado. En estos casos, no existía preocupación alguna por la situación higiénica de estos establecimientos, aprovechándose cualquier lugar que pudiera servir para evitar fugas como espacio en el cual llevar a cabo la retención, como ocurrió con los calabozos o estancias de palacios y fortalezas o de otros grandes edificios. $^{26}$

Estructuralmente, con habitualidad se trataba de lugares en los cuales penetraba escasamente la luz natural, la ventilación se podía calificar de muy deficiente y la salubridad era nimia, o incluso nula. Otro carácter destacable era la congregación de todos los presos en salas, sin que existiera ningún tipo de aislamiento, por tanto se producía una transmisión total entre los presos de enfermedades y de ciertos aspectos del carácter físico $\mathrm{y}$ moral $^{27}$.

Ahora bien, fue durante el siglo XVI cuando comenzó a aparecer por algunos territorios europeos, establecimientos cuya finalidad era la de internar y corregir a determinados sujetos envilecidos de la sociedad, como ocurría con los malhechores, con los mendigos o con las prostitutas. En este sentido, se pueden mencionar la "House of Correction" (1552) en Londres, la Casa de Corrección "Rasphuis"28 (1596) en Ámsterdam, o los distintos "Schellenwerke" en Suiza.

Sin embargo, fue en el preludio del siglo XVIII — concretamente en 1704-, cuando se construyó por primera vez un edificio concebido únicamente para la ejecución de las penas privativas de libertad. Se trata de la Casa de Corrección de San Miguel en Roma ${ }^{29}$, que fue levantada por encargo del Papa Clemente XI. Este establecimiento, agrupaba una serie de celdas exteriores en línea, y constituyó el primer paso para brindar al recluido un alojamiento individual con adecuadas condiciones higiénicas, de ventilación y asoleamiento. ${ }^{30}$

\section{La Ilustración y las voces reformistas ${ }^{31}$}

\footnotetext{
${ }^{25}$ CUELLO CALÓN (1968), p. 302.

${ }^{26}$ Como ejemplo de ello es mencionable la Torre de Londres, la Bastilla de París, el asilo de alienados de Bicêtre, el Hospital de la Salprêtrière, el castillo de Vicennes, que muchas veces se trataron de fortalezas de ciudades, a las que posteriormente se les dio otra funcionalidad. En este sentido, en España es relevante el caso de la Cárcel de Sevilla.

${ }^{27}$ FRAILE (1987), pp. 103-105.

${ }^{28}$ Véase Figura 1 -Anexos-.

${ }^{29}$ Véase Figura 2 -Anexos-.

${ }^{30}$ GARCÍA BASALO (2002), pp. 27-44, pp. 29-31.

${ }^{31}$ Este proceso no es rápido, ni resulta concluso de la noche a la mañana. Es más, aún hoy está por terminar. Se puede aventurar que siempre existirán aspectos por mejorar, por lo que es un desarrollo que por su propia naturaleza será siempre inacabado e incompleto. Por ende, se han ofrecido y se ofrecerán respuestas, críticas y soluciones, por parte de multitud de pensadores, y ellos han sido los que han marcado la evolución en lo que debe ser considerado el castigo en el ámbito punitivo.
} 


\section{1. Las bases ideológicas de la reforma penal ilustrada}

A partir del siglo XVIII el derecho a castigar del monarca, que era considerado como un ser supremo como consecuencia de su origen divino, empezó a desvanecerse debido a los excesos y arbitrariedades acaecidas en las centurias venideras por parte de los ostentadores del poder político. Estos abusos, que fueron el resultado de considerar el castigo una facultad personal del soberano, provocaron arbitrariedades de su parte, hasta el punto de ejercer sus derechos sin control, invistiéndose de un sobrepoder que identificaba al rey con la justicia.

Por lo tanto, empezaron a surgir voces reformistas y discrepantes con estas formas de castigo, que propugnaban una nueva administración y gestión del poder de castigar, toda vez que ello no significaba castigar menos sino mejor. ${ }^{32}$

De este modo, a partir de entonces fue "como si a la justicia - a sus administradores - le diera vergüenza atacar el cuerpo de tal manera", ${ }^{33}$ produciéndose entonces un relajamiento de la acción sobre el cuerpo del delincuente, que pasó a ser un mero instrumento o intermediario en el cumplimiento de la pena. Es cierto que se continuó interviniendo sobre él —incluso en la actualidad-, pero con la finalidad de privar al individuo de una libertad considerada simultáneamente como un derecho y como un bien, en detrimento del sufrimiento físico, del dolor mismo del cuerpo, que ya no constituían elementos que fundamentaban la pena.

Esta notable mudanza en los postulados, vino de la mano de las ideas de los grandes autores ilustrados, ${ }^{34}$ que al igual que en otras disciplinas, resquebrajaron y transformaron diametralmente los cimientos básicos en los que se asentaba el poder absoluto monárquico, y con ello, también revolucionaron el modo de castigar.

En primer lugar, son mencionables las aportaciones de Charles Louis de Secondât, Barón de la Brède y de Montesquieu. Este pensador político francés justificaba la necesidad de que se elaboraran leyes en la que aparecieran los castigos, enunciando por vez primera el principio de legalidad penal. Igualmente, ese castigo sería justo porque gracias a la amenaza de pena impuesta en el "tipo penal" se le protege a todos los miembros de la sociedad, y al propio delincuente se le ha estado protegiendo hasta el mismo instante en que él ejecuta el delito. ${ }^{35}$

No obstante, la aportación más sobresaliente del de la Brède fue la de precisar la forma que ha de adoptar ese derecho a castigar, materializándolo en el poder judicial. Este poder "no debe darse a un Senado permanente, sino que lo deben ejercer personas del pueblo —nombradas de la forma que explicite la ley_-, que formen un Tribunal que sólo dura el tiempo que la necesidad lo requiera, haciéndose el poder de juzgar invisible y nulo al no estar ligado a determinado estado o profesión". ${ }^{36}$ De esta manera, "se impersonaliza el

\footnotetext{
${ }^{32}$ FOUCAULT (1990), p. 86.

${ }^{33}$ FOUCAULT (1990), pp. 17-19.

${ }^{34}$ La Ilustración intentó poner coto al poder, para ordenarlo de una manera más adecuada. Véase ANITUA (2004), p. 17.

${ }^{35}$ Montesquieu lo ejemplificaba así: "Lo que hace lícita la muerte de un criminal es que la ley que lo castiga se ha hecho a favor suyo. Un asesino ha disfrutado de la ley que ahora le condena, pues le ha conservado la vida a cada instante, y por eso no puede reclamar contra ella". Vid. MONTESQUIEU (1972), pp. 53-54. ${ }^{36}$ MONTESQUIEU (1972), p. 152.
} 
derecho a castigar, se diluye y hace invisible, pero precisamente por ello, se vuelve omnipotente". 37

Respecto de las condiciones que la pena debía cumplir, Montesquieu comenzaba hablando de la objetividad uniendo pena y delito, de este modo, no era el hombre el que castigaba al hombre, sino que era el propio delito el que generaba la pena, seguido de la moderación y la proporcionalidad, a fin de que las penas guardaran entre sí una armonía, porque era lógico que se pretendiera evitar de una manera más clara un delito grave que uno menos grave.

Por su parte, Jean-Jacques Rousseau partía de un principio básico —coincidía con Montesquieu-, en que la única forma de legitimar cualquier poder era por medio de la convención o el contrato. Decía que "puesto que ningún hombre tiene una autoridad natural sobre sus semejantes, y puesto que la fuerza no produce ningún derecho, quedan pues las convenciones como base de toda autoridad legítima". ${ }^{38}$ Sin embargo, sus apuntes sobre el castigo fueron bastante exiguos, declarando que éste servía para colocar a cada miembro de la colectividad en su parcela de libertades, evitando que se apropiase de la de otros, debiendo servir la pena como un instrumento que permitiera acomodar las voluntades individuales a un determinado orden, transformando a un ser inútil para la sociedad en alguien que le otorgase utilidad. ${ }^{39}$

Posteriormente, Cesare Bonesana, Marqués de Beccaria, explicó que para evitar que cada hombre intentara sumergir las leyes de la sociedad en el antiguo caos, se requerían motivos sensibles - penas - contra los infractores de las leyes. ${ }^{40}$ Del mismo modo que sus antecesores, consideraba que el contrato social era el que daba origen al ius puniendi estatal.

Beccaria se decantaba, como Montesquieu, por la moderación en el castigo, mas lo acompañaba de la inexorabilidad. Además, arguiía que la eficacia de tal castigo descansaba en tres pilares fundamentales, a saber: semejanza con el delito, infalibilidad y rapidez de la ejecución, ya que resulta evidente que "es mejor prevenir los delitos que punirlos". ${ }^{41}$ Para lograr dicho objetivo, Beccaria buscó el asiento en la legislación, en la objetividad del proceso de elaboración de la ley, junto con la redacción en un lenguaje claro y simple. Estas leyes debían divulgarse y tendrían una gran difusión en el pueblo.

Además, para el milanés, la pena tenía la finalidad de situar al individuo en unas condiciones tales que lo incapacitaban para producir daño a la sociedad, unido al carácter disuasorio que emanaba de la misma. Por ello, construyó el frontispicio de una nueva penalidad en la que "no es la intensidad de la pena la que hace mayor efecto sobre el ánimo humano, sino su duración". Por lo que, el condenado "recompensa con sus fatigas - mientras se hallaba privado de libertad - a la sociedad que ha ofendido, constituyendo el freno más fuerte frente a los delitos". ${ }^{42}$

\footnotetext{
${ }^{37}$ FRAILE (1987), p. 17.

${ }^{38}$ ROUSSEAU (1999), pp. 24-25.

${ }^{39}$ FRAILE (1987), p. 20-22.

${ }^{40}$ BECCARIA (1969), p. 72.

${ }^{41}$ BECCARIA (1969), p. 180.

${ }^{42}$ BECCARIA (1969), pp. 116-117.
} 
Esta nueva forma de castigar, humanizando los procesos legales del momento, ${ }^{43}$ se caracterizó por el hecho de alargar un pequeño sufrimiento, eso es lo que lo convertía en terrible y potencialmente disuasorio para el eventual infractor.

No obstante, este último aspecto se podía salvaguardar en el sistema punitivo de aquel tiempo - mediados del siglo XVIII-, ya que el de la Lombardia concibió un castigo para el que la sociedad de su tiempo no estaba preparada, y que además, su puesta en práctica requería la construcción de un lugar específico en el que ejecutar esta modalidad punitiva: la prisión.

Ahora bien, en esos mismos años, se fue constituyendo el modelo inglés, que agregaba como basamento sustancial para la corrección al aislamiento. Hanway explicaba que la promiscuidad en prisión únicamente servía para mostrar malos ejemplos o buscar la complicidad o chantaje para eventuales y futuras huídas. De esta manera, el aislamiento evitaba el contacto con esos malos influjos, y así el individuo confinado disponía de un espacio para reflexionar y conversar con su propia conciencia hasta hallar la voz del bien. Por ende, defendía que incluso el trabajo se realizase en solitario. ${ }^{44}$

Estos principios generales también fueron seguidos por John Howard, que si bien no se dedicó tanto al campo de las mejoras en la materia penal, si puso todo su empeño en acrecentar el nivel de vida en las prisiones a través de unas condiciones de vida más humanitarias, incluso desde el prisma administrativo y arquitectónico. Howard criticó duramente las torturas y la insalubridad de las instituciones. Además, se decantó por el trabajo en prisión para regenerar moralmente al reo y disciplinarlo para su salida, de acuerdo a los postulados utilitaristas incipientes de la época. Del mismo modo, se preocupó por la necesidad de la existencia de códigos de conducta, tanto para los prisioneros como para los vigilantes, conociendo cada cual sus derechos y obligaciones. Respecto de las infraestructuras, defendía el sistema celular de celdas individuales para que el condenado pudiera dormir cómodamente al estar sólo. A su vez, esa idea distributiva de los prisioneros mejoraría las labores seguridad del recinto, además de posibilitar la reflexión, introspección y el arrepentimiento del privado de libertad. ${ }^{45}$

Por otra parte, también merece una mención particular Manuel de Lardizábal y Uribe, que aunque no fue tan moderno en sus aportaciones, analizó igualmente los aspectos prácticos de la vida en prisión siguiendo un poco las tesis de Howard. De esta manera, percibió que los presos gozaban de demasiada ociosidad, esto es, disfrutaban de bastante tiempo sin nada que hacer de forma continua, lo que aumentaba la probabilidad de que se pervirtieran unos a otros. Por tal razón, dicho mal "podría remediarse estableciendo en las cárceles algunas labores simples y proporcionadas, en que pudiesen ocuparse los reos". ${ }^{46}$ Es decir, introdujo la idea de que los delincuentes se trasmitían hábitos delictivos entre ellos en la inactividad en la que vivían, sin embargo, esa situación se podía contrarrestar si se les disciplinaba por medio del trabajo, pudiéndose aventurar una génesis de las tesis tratamentales del recluso, ya que entendía al castigo como el modo de corregir al delincuente.

\section{2. La respuesta de la época: el surgimiento de las primeras prisiones}

\footnotetext{
${ }^{43}$ CARO POZO (2013), p. 150.

${ }^{44}$ FOUCAULT (1990), p. 127.

${ }^{45}$ CARO POZO (2013), pp. 154-160.

${ }^{46}$ FRAILE (1987), p. 34.
} 
El hecho inaugural en la historia de la arquitectura penitenciaria, lo constituye la fundación en 1775 del Correccional de Gante ${ }^{47}$ — de planta octogonal, cuyas celdas se hallaban rodeando un patio central, facilitando, de este modo, las labores de vigilancia desde aquel—, en la que se instauró genuinamente el principio de clasificación de los delincuentes. Y es que "arquitectónicamente, Gante puede considerarse como la primera institución penal a gran escala en la que se hizo un esfuerzo consiente para que la arquitectura ayudara a la filosofía del tratamiento". ${ }^{48}$ Asimismo, en dicha institución se organizó todo el trabajo penal en torno a los imperativos económicos, ya que se creía que los malhechores no ostentaban dedicación alguna, sino más bien, se trataba de sujetos holgazanes cuya forma de vida era la mendicidad. Por ello, en la prisión de Flandes se procedió a garantizar el trabajo y su pedagogía a todos aquellos que se mostraban reacios al mismo, con el objetivo de desarrollar en el individuo perezoso la afición al trabajo, lo que le permitiría vivir a la salida del correccional. A mayor abundamiento, la estancia en prisión no debía ser lo demasiada corta - ya que no despertaría del letargo interior el espíritu del trabajo en ellos_-, mas tampoco demasiada larga, como sería la perpetuidad en el encierro - ya que la misma los desesperaría y no sentirían motivación por arraigar en su fuero interno la esencia trabajadora, estando más preocupados en proyectos de evasión-. ${ }^{49}$

Respecto de las tesis inglesas, cabe decir que sólo se construyó una penitenciaría que cumplía con los requerimientos exigidos por los autores ingleses, la de Gloucester ${ }^{50}$. Y para mayor veracidad, ni siquiera ésta respondió totalmente a tales principios - sino que sólo parcialmente acogió el esquema inicial—, puesto que el confinamiento absoluto únicamente se utilizaba para los criminales más peligrosos, y para el resto, el trabajo en común durante el día y la separación de noche. ${ }^{51}$

\section{El replanteamiento hacia la vigilancia: la disciplina utilitarista}

\section{1. Las sociedades de control ${ }^{52}$}

Algunos autores se decantan por declarar que la modificación en el planteamiento y la construcción de las prisiones se deben únicamente a criterios economicistas ${ }^{53}$, toda vez que los sistemas económicos vigentes en una sociedad determinada, amparan concretas formas de castigo, que son anejas a estos sistemas económicos en cuestión. ${ }^{54}$

\footnotetext{
47 Véase Figura 3 -Anexos-.

48 JOHNSTON (1973), p. 13.

${ }^{49}$ FOUCAULT (1990), pp. 125-127.

${ }^{50}$ Estuvo abierta de 1791 a 2013, no obstante había sido reformada en varias ocasiones.

${ }^{51}$ FOUCAULT (1990), p. 128. Mientras tanto, en España se suprimió en esos años la pena de galeras (1748), lo que dio lugar a que las penas privativas de libertad tuvieran características puramente militares, hasta pasado un tercio del siglo XIX. Esta pena de prisión consistía en recluir a los internos en PresidiosArsenales -baluartes o fortalezas para defender las costas de algún lugar, hallándose el edificio azotado por el viento, la pleamar y el salitre-, en Presidios Peninsulares o Industriales, en los presidios africanos -para los más problemáticos la reclusión era en fuertes militares en África- o en las casas de corrección -para vagos y mendigos-, todas con un claro tamiz militar, en las que el recluso descontaba su pena por medio de un trabajo reglamentado. Véase, GARCÍA VALDÉS (1986), pp. 771-777.

${ }^{52}$ Es Foucault el que se encargó de desarrollar las tesis sobre las mismas, explicando sus características, su funcionalidad y su finalidad. Véase, FOUCAULT (1990).

${ }^{53}$ MELOSSI y PAVARINI (1980), passim; VON HENTIG (1969), pp. 185-187.

${ }^{54}$ En este sentido, podrían mencionarse las revisionistas, que explicaba la vinculación y el nexo de unión entre la prisión y la fábrica -en este sentido véase la nota al pie anterior-. Otros estudiaron las relaciones
} 
No obstante, en las décadas que van desde las postrimerías del siglo XVIII al inicio del XIX, es cuando comenzó el afloramiento de las sociedades de control. A partir de entonces, el encierro, la vigilancia y la disciplina persiguieron al individuo allá a donde éste se dirigiese, desde la familia hasta la prisión — lugar de reclusión por antonomasia, pasando por la escuela, el cuartel, la fábrica o el hospital.

De este modo, parece que fue Napoleón ${ }^{55}$ el que instauró totalmente esa sociedad disciplinaria. En ella, se produjo una nueva formalización del sistema punitivo - apareció el pueblo soberano frente al soberano, la disciplina frente al suplicio, poder positivoconstructor frente al negativo-represor y se generalizó la prisión como forma de castigo, lo que provocó una transformación sin precedentes en la forma de administrar los castigos $^{56}$.

En primer lugar, la disciplina consiste en distribuir de una determinada manera a los individuos, de acuerdo a las necesidades que se pretendan paliar. De este modo, "el espacio disciplinario tiende a dividirse en tantas parcelas como cuerpos o elementos que repartir hay". ${ }^{57} \mathrm{La}$ arquitectura adquirió, por ende, un papel capital, ya que a través del arte de la construcción se podían proyectar lugares que facilitasen el control de los sometidos a mencionado rigor, así como permitir la creación de espacios útiles, y que en cierta forma interrumpieran las comunicaciones - eventualmente - peligrosas. Además, los elementos eran intercambiables, ya que se usó como base a la jerarquía, que seguía a su vez un esquema matricial, esto es, un sistema de doble entrada donde las filas y columnas de distintas categorías se cruzaban y determinaban el lugar que ocupaba en cada clasificación, llegándose a una ordenación "celular" de los individuos si era menester. ${ }^{58}$

En segundo lugar, el control de la actividad. Supervisión que debía llevarse a cabo estableciendo un correcto empleo del tiempo, a través de la fijación de los ritmos, y en la precisión y la regularidad de las tareas, al punto de llegarse a afirmar que se debía estudiar los movimientos y gestos necesarios para realizar las distintas labores. De este modo, se imponía aquellos que lograban una mayor eficacia y rapidez — esto es, una mayor eficiencia-, y se acababa con los tiempos improductivos u ociosos. Por tanto, las actividades quedaban dispuestas en serie, aprendiéndose los procesos por el individuo gradualmente. ${ }^{59}$

entre las políticas penales y del castigo, respecto de diversos factores sociales -entre ellos la propia economía fordista-. Posteriormente, tras la Segunda Guerra Mundial se ha comentado que hubo un traspaso desde un Estado del Bienestar -en el que la población carcelaria descendió notablemente en los países occidentales hasta mínimos históricos, debido al clima de tolerancia social- a un Estado Penal -vengativo, reaccionario, correccional-, que algunos sitúan a finales de los setenta, con la elección presidencial de Reagan en los Estados Unidos - este cambio algún autor lo sitúa en ese mencionado traspaso de la concepción estatal, unido a la pérdida de vigor del ideal rehabilitador y al alto control racial-. Véase, DE GIORGI (2016), pp. 45, 55-57; GARLAND (2001), p. 34; WACQUANT (1999), pp. 40-46.

${ }^{55}$ Napoleón aplicó y llevó a la práctica parte de los fundamentos ilustrados, como promover la codificación, la cual es un claro ejemplo de limitación del poder, evitándose las arbitrariedades conforme al principio de legalidad. Véase, BERGALLI (1999), p. 550-552.

${ }^{56}$ FOUCAULT (1990), pp. 33-34.

${ }^{57}$ FOUCAULT (1990), p. 146.

${ }^{58}$ FOUCAULT (1990), pp. 147-153.

${ }^{59}$ FOUCAULT (1990), pp. 153-166. 
En tercer lugar, era relevante el papel jugado por la enseñanza mutua, para que los oprimidos por el poder de la disciplina que ostentaban un mayor grado de conocimiento en la ejecución de las labores, realizasen funciones de simple control o vigilancia, aunque no por ello dejarían de aprender, puesto que continuarían con su enseñanza.

Por último, las órdenes debían ser claras y breves, sin que requiriera de explicación ni formulación. Sólo quería obtenerse una inmediata reacción, sin réplica alguna, para mantener el ritmo disciplinario en un ambiente de silencio absoluto. ${ }^{60}$

Por todo ello,

\begin{abstract}
"puede decirse que la disciplina fabrica a partir de los cuerpos que controla cuatro tipos de individualidad, o más bien una individualidad que está dotada de cuatro características: es celular (por el juego de la distribución espacial), es orgánica (por el cifrado de las actividades), es genética (por la acumulación del tiempo), es combinatoria (por la composición de fuerzas)" ${ }^{61}$
\end{abstract}

Mas para la implantación de esa disciplina se precisaba de una estructura arquitectónica distinta a las habituales en la época. Por dicha razón, se debilitó la idea de la construcción ornamentada, majestuosa, donde primaba la ostentación. Lo mismo ocurrió con la relevancia concedida a la vigilancia del exterior, que decayó en importancia, para prestarse atención al control interno del edificio, de los individuos que se hallaban dentro, puesto que la propia edificación debía ser útil para transformar la conducta de los internos en ellos. Consecuentemente, se hizo trascendental la estructura que permitía observarlo todo, disciplinando y vigilando, constantemente, con una simple mirada. Fue así como se pudo dominar el cuerpo sin agredirlo, se pudo controlar al individuo sin recurrir a la violencia ni a la fuerza. ${ }^{62}$

\title{
4. 2. El panóptico
}

Ante la consolidación de la doctrina disciplinaria, surgió el Panóptico de Jeremy Bentham, que se constituyó como la figura arquitectónica de esta nueva composición, toda vez que se fundamentaba en la posibilidad de controlar desde un único punto punto de inspección central - lo que estaba sucediendo en una infinidad de lugares. La fórmula sobre la que se asentaba el Panóptico era eminentemente sencilla: "el edificio ha de garantizar la existencia de un punto por todos observado, y desde el que cada uno piensa que puede ser controlado en cualquier momento". ${ }^{6}$

Parece evidente que la estructura edilicia ideada por el padre del utilitarismo, incorporaba novedosos materiales y empleaba multitud de elementos arquitectónicos nunca usados para el particular fin de la prisión. En este sentido es destacable que se hizo uso de ventanas, con el objetivo de facilitar la penetración de la luz, mejorar las condiciones higiénicas y de sanidad, y obviamente, para allanar la misión del planteado edificio. En palabras del propio iniciador de esta arquitectura, "quitar a un hombre su libertad no es

\footnotetext{
${ }^{60}$ FOUCAULT (1990), pp. 166-171.

${ }^{61}$ FOUCAULT (1990), p. 172.

${ }^{62}$ FOUCAULT (1990), pp. 172-182.

${ }^{63}$ FRAILE (1987), p. 132.
} 
condenarle a padecer frío ni a respirar un aire fétido", ${ }^{64}$ puesto que la cárcel debía ser útil, en vez de incómoda, para que el trabajo de los internos mantuviera la productividad. ${ }^{65}$

Respecto a la forma del edificio, ${ }^{66}$ éste debía ser "en la periferia, una construcción en forma de anillo; en el centro, una torre, ésta, con anchas ventanas que se abren en la cara interior del anillo", ${ }^{67}$ En la zona circular, se hallaban las celdas que se construirían ocupando toda la anchura del edificio, mientras que, el lado que daba al exterior, como el que se ofrecía a la torre central, estaría provisto de amplios ventanales para que cada calabozo individual fuera atravesado por la luz, y mediante las siluetas sombreadas que brindaba ésta, se pudiera conocer desde la torre central, la actitud que estaba teniendo el preso en todo momento. Además, aunque se hacía una utilización tremenda y suficiente del vidrio, las celdas lateralmente quedaban separadas por muros para que el individuo no pudiera entrar en contacto con los otros privados de libertad. En definitiva, el interno era vigilado, pero él no podía observar nada; informaba al vigilante, sin embargo, no podía comunicarse con nadie; y eso es lo que hacía de este modelo arquitectónico un diseño extremadamente seguro, puesto que se evitaban los contactos, los contagios en la moral, y las conspiraciones para escapar del lugar. ${ }^{6}$

A mayor abundamiento, el funcionamiento del Panóptico se basaba en el juego del poder sobre el individuo recluido, ya que éste se sentiría constantemente observado, aun cuando no lo estuviera, o incluso cuando no existiera vigilante en la torre central. Sin embargo, esa sensación simplemente era lo que lo enclaustraba y evitaba conductas evasivas. En palabras de Foucault, "lo esencial es que se sepa vigilado, [... aunque], no tiene necesidad de serlo efectivamente". ${ }^{69}$ Es decir, el interno se sentía coaccionado por un poder, en cierto modo ficticio, pero que era tanto más real en cuanto el individuo se lo representaba sobre sí.

Además, parece evidente que el modelo "que todo lo ve" cumplía con otra premisa básica para la época, pues era claramente economizador a la vez que efectivo, ya que permitía poder controlar a un mayor número de personas, con un número menor de supervisores - que idealmente nunca debían intervenir e interactuar con los presos_- ${ }^{70}$.

\section{3. La puesta en práctica de las ideas benthamianas en la arquitectura penitenciaria}

A pesar de la revolución que significó el Panóptico, el éxito del edificio diseñado por Bentham fue relativamente escaso, ya que aunque provocó un claro influjo en las prisiones que se levantaron con posterioridad - caso de la cárcel de Richmon en Virginia o Milbank-, éstas no siguieron la estructura arquitectónica del verdadero planteamiento benthamiano. Así lo declaraba Markus:

"las ideas de Bentham se volvieron muy influyentes. Aunque se construyeron muchas prisiones con disposición central, algunas declarando ser Panópticas, [...] ninguna lo fue. Les faltaba esa asimetría total de poder que era una característica esencial. Los internos podían ver y escucharse entre ellos, podían ver a los

\footnotetext{
${ }^{64}$ BENTHAM (1839), pp. 43-44.

${ }^{65}$ Se debe entender en que en la época benthamiana ya han nacido los postulados del liberalismo económico.

${ }^{66}$ Véase Figura 4 -Anexos-.

${ }^{67}$ FOUCAULT (1990), p. 203.

${ }^{68}$ FOUCAULT (1990), pp. 203-204.

${ }^{69}$ FOUCAULT (1990), p. 205.

${ }^{70}$ FOUCAULT (1990), pp. 205-208.
} 
inspectores, o habían períodos de tiempo en los que podían escapar de la vigilancia". ${ }^{71}$

Ahora bien, las ideas emanadas del panoptismo benthamiano contribuyeron también a demostrar y advertir el acuciante fracaso que estaba sufriendo el sistema punitivo instaurado en el siglo XVIII, constituyendo la base para cruzar hacia el nuevo sistema. ${ }^{72}$

En relación a lo que a la edificación de las cárceles se refiere, se debe advertir que durante el siglo XIX se intentó crear realidades arquitectónicas más baratas, en términos de coste por unidad, por lo que se abogó por presidios más grandes, renunciándose a la idea del panóptico puro y optándose por encerrar en una misma penitenciaría a penados con diferentes tipos de condena. Bajo dicha premisa de rebajar los costes fue como se transformó el panóptico original, en el panóptico-local, en el cual tenía cabida un número mayor de reos, mediante la utilización de aspectos de la forma radial: puesto que del centro con forma circular — donde se debían hallar los servicios comunes - surgían las partes o radios, que era el lugar donde se encontraban las celdas divididas por una pared medianera a lo largo del piso, lo que permitía hacer divisiones según el tipo de preso. De este modo, desde el centro de la prisión se podía vigilar los aposentos, los talleres, los patios, e ir inmediatamente de un lugar a otro del establecimiento. ${ }^{73}$

Por tanto, esos años se caracterizaron principalmente por la consolidación de las estructuras arquitectónicas que se vinieron desarrollando idealmente en el siglo anterior, y por la formulación y construcción de prisiones que serían hijas de tales influencias. Ahora bien, no existió un modelo puro o único en cada lugar, sino que cada presidio se levantó de acuerdo a lo que se estimó más conveniente en cada momento y emplazamiento, no obstante, casi todas las edificaciones siguieron las teorías y líneas de pensamiento emanadas con anterioridad o durante el trascurso de ese mismo siglo.

De este modo, en 1829, se construyó en Filadelfia la Eastern Penitenciary ${ }^{74}$ — también conocida como Cherry Hill— ${ }^{75}$ que planteó por vez primera la estructura celular. Fue la primigenia prisión en la que se aplicó el aislamiento continuo de los reclusos entre sí, ${ }^{76}$ lo que permitía el tratamiento a través de programas específicos según el tipo de delito cometido. A mayor abundamiento, es destacable la planta que utilizó el arquitecto inglés, John Haviland, puesto que se apoyó en un modelo radial, en torno a siete edificios, donde se encontraban las celdas, que venían a converger como alas en una estructura circular central, desde el cual los vigías cumplían con sus labores de inspección, control y supervisión, mejorando la vigilancia de cada ala por parte de los guardias - se observan los pasillos de los radios-, y la seguridad de los mismos en el ejercicio de su función, pudiéndose controlar individualmente a cada recluso en su propia celda por una abertura existente en la puerta. Además, cada radio contaba con unas cuarenta celdas individuales por planta, con retretes, agua potable y calefacción, por lo que se mejoró considerablemente las condiciones de vida de los internos. ${ }^{77}$

\footnotetext{
${ }^{71}$ MARKUS (1993), p. 123.

${ }^{72}$ FRAILE (1987), pp. 136-137.

${ }^{73}$ LÓPEZ (1832), pp. 54-55.

${ }^{74}$ Véase la Figura 5 -Anexos-.

${ }^{75}$ Este modelo fue utilizado también en Latinoamérica, como por ejemplo en la antigua Prisión Central de Lima de 1862.

${ }^{76}$ CADALSO (1913), p. 104.

${ }^{77}$ CARO POZO (2011), pp. 9-11.
} 
Así fue cómo emergieron algunos de los sistemas penitenciarios de encarcelamiento que nos llegaron hasta el siglo pasado, con mayor o menor repercusión, como son los casos del sistema Auburn y el modelo de Filadelfia. El primero, también denominado Régimen del Silencio, ${ }^{78}$ se particularizaba por usar la celda individual durante la noche, mas las comidas y el trabajo del recluso se efectuaban en común, pero eso sí, en el más absoluto silencio, ya que estos tenían prohibido hablar. Así, el sujeto estaba en contacto con los demás, lo que le beneficiaba en su socialización, no obstante, estaba sometido a una férrea disciplina garantizada por la vigilancia y el castigo, lo que hacía que el individuo aprendiese a vivir en comunidad, ya que se readaptaba obteniendo hábitos para con la sociedad, a la vez que se le instruía en el conocimiento de que ésta posee reglas de comportamiento que es necesario respetar. Este modelo se aplicó por primera vez en 1823 en la Ciudad de Auburn - en el Estado de Nueva York- e implantado en la cárcel de Sing Sing. ${ }^{79}$ Con este modelo se imposibilitaba la eventualidad de posibles motines o fugas y se evitaba los contactos diferenciales entre los retenidos y los funcionarios. ${ }^{80}$

Por su parte, el sistema Filadélfico o celular, ${ }^{81}$ se caracterizaba por ser un modelo de aislamiento absoluto. En él la readaptación del individuo venía de la mano de la relación existencial del penado con su propia conciencia, porque la soledad era un instrumento positivo de reforma de su moralidad, ya que el sujeto gozaría de mucho tiempo dedicado a la reflexión de su crimen, siendo el propio preso el regulador de su pena. En este régimen, el trabajo serviría de consuelo - ya que despejaría al sujeto del tormento de su mente-, más que considerarse una obligación, ${ }^{82}$ aunque a veces "no se les permitía ni siquiera trabajar por temor a que esto los pudiera apartar de la meditación ${ }^{83 "}$. Este régimen se introdujo por primera vez en la prisión de Walnut Street, Filadelfia, en 1787, separando celularmente al recluso de día y noche, para que éste retornara al camino de Dios. Posteriormente, se trasladó el sistema a otras penitenciarías como Cherry Hill, a otras de Pensilvania, e incluso se usó en Europa en la primera mitad del siglo XIX. No obstante, fue y ha sido duramente criticado, puesto que el recluso se veía desprendido de todas sus aptitudes sociales, culturales y psíquicas, creándose seres marginales y alineados. ${ }^{84}$

Dicho esto, y volviendo a la senda puramente arquitectónica, se debe explicar que la construcción radial en forma de estrella, se asentará en España y el mundo durante el siglo XIX, en tanto en cuanto se trataba de un modelo que permitía una eficaz y dinámica ampliación alargando simplemente los brazos, sin perder de vista sus atributos panoptistas. Su introducción en el país ibérico vino de la mano del publicista Marcial Antonio López tras el encargo encomendado por Fernando VII en 1832 para desarrollar una reforma penitenciaria a partir de la observación de los establecimientos existentes en Europa y Estados Unidos. Ergo, no es de extrañar que a partir de entonces apareciesen multitud de prisiones que contuvieran estos principios estructurales, en mayor o menor medida, mas sin existir una estrategia globalizadora que estableciera el marco general a la hora de abordar el encauzamiento y la configuración de los espacios penitenciarios. De

\footnotetext{
${ }^{78}$ También denominado sistema de Nueva York. Vid. MOSQUEA GARCÍA (2019), p. 41.

${ }^{79}$ FOUCAULT (1990), p. 240.

${ }^{80}$ Véase Figura 6 -Anexos-.

${ }^{81}$ También denominado sistema de Pennsylvania o sistema separado. Vid. BADARÓ BAPTISTA (2015), p. 80.

${ }^{82}$ FOUCAULT (1990), pp. 241-242.

${ }^{83}$ RUSCHE y KIRCHHEIMER (1984), p. 151.

${ }^{84}$ CONDE-PUMPIDO FERREIRO (1990), p. 597.
} 
este contexto son los casos de la Cárcel Modelo de Valladolid ${ }^{85}$ (1849), la Cárcel de Vitoria (1861), la Cárcel Modelo de Madrid (1884) o la Cárcel Modelo de Barcelona ${ }^{86}$ $(1904)^{87}$. Una excepción al modelo radial fue, en 1852, la Cárcel de Mataró, que ostentaba una planta efectivamente benthamiana, pero en forma simplemente semicircular ${ }^{88}$.

$\mathrm{Al}$ igual que en España, el modelo radial adquirió una importancia radical en los diversos países a uno y otro lado del Atlántico, ya que los gobiernos estatales comenzaron a enviar a arquitectos e investigadores para analizar las bondades del modelo penitenciario de la prisión de Eastern State en Filadelfia, ante la creciente fama que a principios del siglo XIX iba adquiriendo este modelo debido a la facilidad en las labores de vigilancia y control de los reclusos que se hallaban aislados en celdas individuales, lo que fortalecía la seguridad del establecimiento mismo y de los guardias o supervisore-. De esta época es, por ejemplo, la prisión de Pentonville ${ }^{89}$ (1842), en Barnsbury, Londres, en la que se utiliza el sistema radial en abanico, con pabellones de tres niveles para reducir su longitud. ${ }^{90}$

Del mismo modo, tan relevante y de tanto calado fue la difusión por América Latina de la arquitectura propia del sistema iniciado en Filadelfia, que el penólogo norteamericano Negley Teeters realizó una expedición por todo el sur de América, visitando sus prisiones, obteniendo de dicho viaje una conclusión:

\begin{abstract}
"Pese a que todas esas penitenciarias son llamadas, en la mayoría de los países, Panópticos, siguiendo la creación del fantástico alarde de Jeremy Bentham, en toda Sudamérica no existe un panóptico real, $[\ldots]$ desde la Penitenciaría de Santiago ${ }^{91}$ construida en 1843 [...] hasta la de La Paz, terminada en 1896, encontramos la clara influencia de la Penitenciaría de Filadelfia. Todas ellas son variantes arquitectónicas del divinamente inspirado sistema de los reformadores de Filadelfia". ${ }^{92}$
\end{abstract}

En este sentido, igualmente se puede observar ejemplos de este fenómeno en la República Argentina, ya que la prisión de Mendoza (1864), la Penitenciaría de Buenos Aires o Penitenciaría Nacional ${ }^{93}$ (1874) de Ernesto Bunge — en lo que actualmente es el Parque de las Heras-_ o el Presidio de Ushuaia (1904) siguen la misma estructura radial, fundamentalmente en forma de abanico, al estilo de la de Pentonville.

Por ende, la evolución de la morfología edilicia en los diversos países siguió en esos más de cien años similares derroteros, aunque eso sí, en cada lugar el influjo de los modelos fueron más o menos tardíos, y en cada edificación se podía encontrar peculiaridades singulares para adaptarlas a las particulares circunstancias de cada construcción, mas siempre bajo las premisas preestablecidas de un pseudo-panoptismo que se amparaba en el modelo radial.

\footnotetext{
85 Esta prisión adhirió aspectos del panóptico inútiles al no incluir referencias que para Bentham eran elementales -como la zona de vigilancia central o el hacinamiento de reclusos en pabellones-, lo que rompía con las pretensiones de control que fundamentaban el sistema panóptico.

${ }^{86}$ Véase Figura 7 -Anexos-.

${ }^{87}$ FRAILE (1987), pp. 181-210.

${ }^{88}$ FRAILE (1987), pp. 159-160.

${ }^{89}$ Véase Figura 8 -Anexos-.

${ }^{90}$ CARO POZO (2011), pp. 9-12.

${ }^{91}$ Véase la Figura 9 -Anexos-.

92 GARCÍA BASALO (2006), pp. 118-119.

${ }^{93}$ Véase Figura 10 -Anexos-.
} 


\section{De la decadencia de las sociedades de control a la reeducación}

\section{1. El cambio de paradigma: la prevención y la resocialización del reo}

Durante el siglo XIX aparecieron una serie de autores que se enfrentaron a los postulados penales clásicos emanados en el siglo anterior. Este fenómeno filosófico - que buscó acomodo en las ciencias naturales - trascendió al ámbito criminal, denominándose positivismo criminológico.

A partir de entonces, la criminalidad fue abordada de una manera distinta, con un método menos dogmático y más científico, adquiriendo un papel central a la hora de estudiar al delincuente, el tema de la prevención del delito, en base al entendimiento de las causas de la delincuencia.

En este sentido, Ferri elaboró multitud de medidas preventivas y que eliminaban la peligrosidad del sujeto delincuente: entre ellas, observó las necesidades tratamentales del autor de una conducta delictuosa para alejarlo de su tendencia al delito, así como imponía como vital las tareas de individualizar la pena a cada penado, conforme a sus requerimientos. ${ }^{94}$

De este modo, se puede afirmar que bajo el parapeto de los avances y de las teorías filosófico-penales desarrolladas a lo largo del siglo XIX, prosperaron y se expandieron durante la centuria pasada las teorías de la prevención especial, que propugnaban, en ese castigar de una mejor forma, la reeducación del condenado, a través de la readaptación y reforma del carácter de éste en la medida que fuera posible, ya que de otro modo se segregaba a los inadaptables. ${ }^{95}$

Además, se tiene que tener en cuenta que la prevención especial también fue hija de la doctrina pedagógica penal, ya que esta última pretendía un cambio en la moralidad del condenado y, como régimen terapéutico, también perseguía desprender de su peligrosidad al sujeto privado de libertad, por lo que la pena de prisión se convertía puramente en una especie de rehabilitación por medio de un tratamiento cuasi médico. ${ }^{96}$

Posteriormente, con el devenir de los años, máxime ante el influjo incesante de disciplinas de las ciencias sociales como la sociología o la antropología, esta senda desembocó en las posturas resocializadoras del reo, ya que se debía entender que la sociedad fue la que ha fallado en el proceso de socialización del delincuente al no saber inculcarle los valores sociales que el victimario desdeñó. Por eso, el tratamiento reparador en estos casos se fundamentaba y — aún hoy se debe fundamentar - en la reeducación, readaptación y reinserción social del condenado. ${ }^{97}$

Como consecuencia de lo anterior, se adoptaron por parte del Primer Congreso de las Naciones Unidas sobre Prevención del Delito y Tratamiento del Delincuente las Reglas Mínimas para el tratamiento de los reclusos, celebrado en Ginebra en 1955, y aprobadas por el Consejo Económico y Social en sus resoluciones de 31 de julio de 1957, y

\footnotetext{
${ }^{94}$ ELBERT (2001), p. 51.

95 TINEDO FERNÁNDEZ (2008), p. 33.

${ }^{96}$ FERRAJOLI (1998), p. 265.

${ }^{97}$ ZAFFARONI (1991), pp. 180-181.
} 
posteriormente, también se hizo el 13 de mayo de 1977. Notables fueron las aportaciones realizadas, en este sentido, por la Regla 58 que disponía que "el fin y la justificación de las penas y medidas privativas de libertad son, en definitiva, proteger a la sociedad contra el crimen. Sólo se alcanzará este fin si se aprovecha el período de privación de libertad para lograr, en lo posible, que el delincuente una vez liberado no solamente quiera respetar la ley y proveer a sus necesidades, sino también que sea capaz de hacerlo". Por su parte, la Regla 59 rezaba que "para lograr este propósito, el régimen penitenciario debe emplear, tratando de aplicarlos conforme a las necesidades del tratamiento individual de los delincuentes, todos los medios curativos, educativos, morales, espirituales y de otra naturaleza, y todas las formas de asistencia de que puede disponer". Finalmente, la Regla 63.1 argumentaba que "estos principios exigen la individualización del tratamiento que, a su vez, requiere un sistema flexible de clasificación en grupos de los reclusos. Por lo tanto, conviene que los grupos sean distribuidos en establecimientos distintos donde cada grupo pueda recibir el tratamiento necesario".

\section{2. La aplicación penitenciaria de la Prevención}

Aun cuando los modelos penitenciarios que se pueden venir a denominar "tradicionales ${ }^{98 "}$ se seguirían utilizando en algunos particulares lugares hasta hoy, ${ }^{99}$ se debe afirmar que la marcha evolutiva del siglo XX comenzó con el proyecto elaborado por Henri Poussin en 1898, para la construcción de la Prisión departamental de Fresnesles-Rungins en las afueras de París, que provocaría una transformación preponderante en el ámbito de la arquitectura carcelaria futura.

Este edificio marcó el nacimiento de los Complejos Penitenciarios, los cuales pueden ser definidos como un "conjunto de establecimientos y servicios diferenciados, interrelacionado y coordinado para hacer efectiva una mejor individualización del tratamiento y una efectiva aplicación de las distintas fases de la progresividad del régimen penitenciario". ${ }^{100}$ También, se puede entender dentro del concepto a un conjunto de edificios con diferentes funciones, como puede ser el caso de prisión junto a un tribunal de justicia, lo que permitiría ganar en operatividad, mejorando notablemente el aprovechamiento del suelo a la vez que se evita el traslado de los detenidos por la vía pública, con el riesgo que ello siempre comporta. Además, este tipo de infraestructuras carcelarias se caracterizan por ser autosuficientes y, normalmente, su construcción y el mantenimiento de la población reclusa ostenta un coste mucho menor.

Ante la diversidad de cometidos que debían cumplir desde sus inicios estos Complejos Penitenciarios, se utilizaron construcciones de distinta índole, puesto que el modelo radial se hizo insuficiente, debiéndose optar por otra tipología arquitectónica. En una primera época se utilizó principalmente la forma de espina, sistema paralelo, o también conocido como poste telefónico, basándose en un eje circulatorio central con cuerpos o bloques situados a ambos lados y paralelos entre sí. ${ }^{101}$ Este sistema con sus variantes de peine

\footnotetext{
${ }^{98}$ Caso de los panópticos locales o los modelos radiales, entre otros.

${ }^{99}$ En este sentido, por ejemplo la Cárcel Modelo de Barcelona estuvo abierta hasta 2017, manteniéndose como lugar de reclusión durante 113 años, la Penitenciaría nacional estuvo en funcionamiento en el periodo de 1877 a 1961, o la Prisión de La Santé en París que lleva recluyendo a penados desde 1867 y todavía continúa con su actividad -evidentemente con reformas y modificaciones-.

${ }^{100}$ PAIVA (1966), p. 5.

${ }^{101}$ Respecto de la planta radial tiene las ventajas de una construcción más sencilla, una posibilidad mayor de crecimiento, y con él se elimina los ángulos cerrados o muertos. Además, es más flexible a la incorporación de cambios requeridos por una evolución de la penología, mejora sustancialmente las
} 
simple — celdas y/o pabellones a un solo lado del corredor - y peine doble - a ambos lados-, mejoraba la ventilación, el asoleamiento, la orientación e incluso el movimiento de los reclusos. ${ }^{102}$

Este tipo de diseño fue el que se predominó por todo el orbe durante el siglo XX, debido a la difusión y prédica del arquitecto Alfred Hopkins, que proyectó la Prisión de Lewisburg ${ }^{103}$ (1932) en Pensilvania, o la Penitenciaría Federal de Indiana, ${ }^{104}$ donde se combina el diseño en espina con dos sectores radiales, que llegan hasta los extremos del eje circulatorio. ${ }^{105}$

Como Complejos Penitenciarios de gran relevancia ${ }^{106}$, se pueden destacar: el de Rickers Island (1932) en Nueva York, que cuenta con veinticuatro establecimientos y más de treinta mil internos, siendo la ciudad penitenciaria con mayor población penal del mundo occidental. En Holanda, el de Scheveningen ubicado en La Hay-, o en las inmediaciones de París, la Maison d'Arrêt de Fleury-Mérogis (1968), que se considera el mayor complejo carcelario de Europa occidental. ${ }^{107}$

Otra modalidad arquitectónica del siglo pasado, fue la de los arquetipos o partidos en torre o en altura, que aparecieron en el panorama de las grandes urbes, en las cuales no se podía desaprovechar el espacio. Además, se simplificó con esta solución el problema del transporte de los detenidos gracias a la cercanía a los juzgados y tribunales respecto del lugar de retención. Algunos ejemplos de este arquetipo penitenciario son el Centro de Detención para Jóvenes Adultos de Brooklyn, en New York que cuenta con ocho plantas con pabellones en los que están dispuestas interiormente las celdas de los sujeto- ${ }^{108}$; y la Cárcel de Encausados de la Capital (1979) —Cárcel de Caseros "Nueva" —, 109 en Buenos Aires, que fue construida en forma de $\mathrm{H}$ acostada y contó con veinticinco plantas de tipología en torre concebidas para asegurar el alojamiento individual de mil ochocientos internos procesados. Además, en esta última, los pabellones ocupaban en cada planta las patas largas de la $\mathrm{H}$, con celdas contiguas en forma de peine, mientras las cortas se utilizaban como patio de recreación para los internos y recinto de visitas. ${ }^{110}$

En 1961, por otro lado, surgió el prototipo campus -cuyo nombre deriva de la estructura afín a los campus universitarios- tras su introducción en el Instituto de Jóvenes Adultos de California. Se basa en la idea de subdivisiones funcionales, formando grupos de reclusos más pequeños y homogéneos, y permitiendo en torno a sí una mayor autonomía del mismo, a partir de sus unidades funcionales. El modelo se basa no en único edificio, sino construcciones dispersas en un amplio espacio. Aún hoy se viene construyendo bajo

\footnotetext{
condiciones higiénicas y permite contar con abundantes espacios para la realización de programas, así como, lograr una mayor manejabilidad y movimiento de la población interna.

102 Para algunos autores, este sistema surgido con Poussin no respondía a una concepción diferente de prisión, puesto que las ideas en torno al castigo -durante el positivismo- no variaron las bases anteriores. Véase, ALTMANN SMYTHE (1970), p. 63.

103 Véase la Figura 11 -Anexos-.

104 Véase la Figura 12 -Anexos-.

105 BRUNO (2006), pp. 8-10.

${ }^{106}$ Estos conjuntos cada vez tienen un mayor grado de integración, compartiendo recursos tales como el servicio de alimentación, la capacitación del personal y los servicios de mantenimiento e infraestructura.

${ }^{107}$ GARCÍA BASALO (2003), pp. 59-91, pp. 63-75.

108 BRUNO (2006), pp. 8-10.

109 Véase la Figura 13 -Anexos-.

${ }^{110}$ BRUNO (2006), pp. 12-13.
} 
esta modalidad, como es el caso del recientemente inaugurado (2011) Complejo Penitenciario Federal III, ${ }^{111}$ del Noroeste Argentino. ${ }^{112}$

Como resultado de todas estas novedades arquitectónicas, se establecieron en España los Centros Penitenciarios Tipo, que siguiendo la estructura modular ${ }^{113}$, se convirtieron a partir de la década de los noventa en el prototipo en virtud del cual, se construyeron en los subsiguientes años, las prisiones españolas. ${ }^{114}$

Lo mismo ocurre con otros centros, como los Complejos Penitenciarios de Ezeiza (1999) ${ }^{115}$ o Marcos Paz, en Argentina, donde se hacen eco las voces reformistas y las nuevas formas de hacer justicia, en virtud de mencionado entendimiento del castigo, en torno a la prevención especial.

\section{El entendimiento del castigo en las últimas décadas: entre las postrimerías de la resocialización y el resurgimiento de las sociedades de control}

A pesar de los esfuerzos realizados, la función resocializadora de la pena privativa de libertad no obtuvo los resultados esperados $\mathrm{y}$, poco a poco, cada vez más autores reconocieron su fracaso. ${ }^{116}$ Se debe advertir que parte de este abatimiento socializador se debe a circunstancias de base, como sucedió con las ya mencionadas Reglas Mínimas para el tratamiento de los reclusos de mediados de siglo pasado, que si bien fijaban una serie de estándares mínimos, fueron deficientes en otros aspectos, como el ostentar pretensiones de universalidad. Por tanto, muchos de los compromisos adquiridos en este texto, ya eran anticuados y habían sido superados ampliamente en algunos países; sin embargo, otros eran difícilmente aplicables y ejecutables por la imposibilidad de introducir esas pautas en los ordenamientos particulares. ${ }^{117}$

Igualmente, dejando de lado las Reglas Mínimas, también aparecieron multitud de contrariedades e impedimentos de fondo, que fueron los que mermaron a la prisión como institución, incluso más allá de la resocialización.

En primer lugar, se puede hablar de la utilización masiva y abusiva de la pena de prisión, al no existir otras medidas alternativas en los sistemas punitivos, causando una superpoblación penitenciaria en la mayoría de los países del mundo, lo que ha repercutido enormemente en el incumplimiento efectivo de las pretensiones resocializadoras. ${ }^{118}$

\footnotetext{
111 Véase la Figura 14 -Anexos-.

112 MARGARIÑOS (2008), p. 2.

${ }^{113}$ Esos módulos permitirán una clasificación de los condenados dentro de la prisión, situándolos en uno u otro módulo, según sus necesidades, el tratamiento que se le aplica al interno, su peligrosidad o el grado penitenciario en el que se halla. De este modo, no debe extrañar que existan módulos que estén medianamente vacíos - en torno a un veinte por ciento de su capacidad-, y otros que lleguen casi a su nivel máximo de ocupación -como suelen ocurrir con los de Respeto-.

114 Véase la Figura 15 -Anexos-.

115 Véase la Figura 16 -Anexos-.

${ }^{116}$ La prisión no es natural al hombre y, al igual que hubo momentos en los que no existió, obviamente, esta realidad desaparecerá. Véase, TÉLLEZ (1999), p. 324.

${ }^{117}$ MAPELLI CAFFARENA (2006), pp. 1-4.

118 TÉLLEZ (1996), pp. 99-136, p. 100.
} 
En segundo lugar, es dable destacar que la prisión contiene, esto es, guarda al delincuente de la sociedad, pero no lo corrige. ${ }^{119}$ Hasta tal punto es así, que a partir de los años setenta, los diversos Estados -incluso los férreos defensores de la resocialización-, fueron abandonando en sus cárceles los tratamientos penitenciarios por sus deficiencias: como la incoherencia en el fin perseguido, ${ }^{120}$ los escasos resultados, el asimilar al penado con un enfermo, la afectación de la dignidad humana, o el propio derecho a no someterse a tratamiento. Esta decrepitud, provocó la crisis del fin resocializador, ya que sin tratamiento, el pretendido fin queda vacío de contenido. ${ }^{121}$

En último término, no se debe olvidar la nocividad que produce la vida carcelaria, que lejos de resocializar, contamina al interno y ataca principios básicos de las relaciones sociales en comunidad. La prisión afecta a la salud física y mental del sujeto, creándose más riesgos que en el exterior de entrar en contacto con ciertas enfermedades. También, provoca sufrimientos que alteran considerablemente la personalidad de los individuos encerrados, lo que en definitiva, perjudica antisocialmente al recluso, produciendo efectos negativos en el proceso de integración social. ${ }^{122}$

No obstante, en las últimas décadas han resultado relevantes innovaciones en el campo ideológico-penitenciario, desde dos vertientes. Una, basada en la necesidad de amparar y propugnar nuevamente la necesidad de la resocialización, a través de la reinserción social, eliminando los rasgos perjudiciales de la prisión. Y otra, que se fundamenta en la vuelta a las sociedades de control, pero por medio de las recurrentes técnicas innovadoras y la aplicación tecnológica actual, haciendo uso de la vigilancia irrestricta, de la supervisión y el control omnímodo.

\section{1. Las bases ideológicas en torno a la reinserción}

En este punto, se debe indicar que en la actualidad se ha producido una vuelta a los aspectos más garantistas con los derechos y deberes del condenado, junto con el viraje hacia la observancia de las premisas relativas a la dignidad y humanidad del privado de libertad.

Así, se debe partir de

"la premisa según la cual la reintegración social del condenado no puede y no debe hacerse a través de la pena - detentiva —, sino, contra la pena, vale decir, contrarrestando los efectos negativos que la privación de libertad ejerce sobre sus oportunidades de reinserción". ${ }^{123}$

Por ello, es destacable cómo esta corriente se aleja de la pena para efectuar la "nueva socialización" del individuo, puesto que esa pena sanción va más allá de la privación del derecho a la libertad ambulatoria y, normalmente, conlleva multitud de efectos perjudiciales a la sociabilidad del sujeto, como suele suceder, por ejemplo, con la fractura

\footnotetext{
${ }^{119}$ RUIZ FUNES (1949), pp. 7-8.

${ }^{120}$ Es mencionable que ni siquiera dos profesionales en la materia eran capaces de establecer la línea a seguir, es decir, indicar el tratamiento necesario para los reclusos que hubieren cometido determinado delito. Vid. RUIZ FUNES (1949), pp. 7-8.

${ }^{121}$ TÉLLEZ (1996), pp. 101-104.

${ }^{122}$ TÉLLEZ (1996), pp. 104-107.

${ }^{123}$ BARATTA (1999), p. 72.
} 
de las relaciones familiares y sociales, con la dificultad de las relaciones entre los propios penados, con el choque emocional y psico-social al recuperar la libertad, entre muchos otros. Para contrarrestarlos, hay que decantarse por programas específicos que intenten paliar cada área en la que el condenado puede sentir una merma en su proceso de sociabilización, intentando eliminar todas esas consecuencias negativas de la entrada en prisión. $^{124}$

Evidentemente, este es un campo en mejora, sobre el que aún hoy, sociólogos, juristas, psiquiatras, psicólogos, criminólogos y multitud de especialistas están trabajando, y cuya aplicación será distinta, dependiendo del grado de interiorización de estos en las normas positivas y reglas de los distintos países, lo que redundará, asimismo, en su arquitectura penitenciaria. ${ }^{125}$

Ahora bien, una de las más novedosas normativas en la materia elaboradas ya en el siglo XX es el caso de las Reglas o Normas Penitenciarias Europeas, adoptadas el 11 de enero de 2006, por el Comité de Ministros del Consejo de Europa, que declara principios básicos en sus primeros artículos en lo que a la vuelta a la socialización se refiere. En primer lugar, se puede señalar el principio de reinserción social, en virtud del cual se configura el intento de eliminar las circunstancias que llevaron al fracaso de la resocialización, declarando que el sistema penitenciario no puede pretender cambiar al sujeto, su personalidad o hacerla una persona bondadosa, aunque si puede ofrecer recursos y servicios que le sirvan al interno para superar sus falencias o carencias. En segundo término, se enuncia el principio de normalización social, según el cual la vida en prisión debe desarrollarse de igual forma que en la sociedad libre sin más limitaciones que las relativas a la libertad ambulatoria, permitiendo la ejecución del castigo de una mejor manera y persiguiendo una rehabilitación mayor. ${ }^{126}$

Igualmente, como consolidación de las tesis acerca de la necesidad de tratamiento penitenciario para lograr la inserción del reo en la sociedad, es dable destacar la reciente revisión de las anteriores Reglas Mínimas de las Naciones Unidas de 1957, y la definitiva aprobación, el 4 de mayo de 2015, de las Reglas Mínimas de las Naciones Unidas para el Tratamiento de los Reclusos — Reglas Mandel_-, por la misma Asamblea General.

De este modo, la primera regla que contiene el texto en cuestión hace alusión al respeto a la dignidad de los encarcelados en cuanto seres humanos. La tercera y la quinta, por su parte, reconocen la naturaleza aflictiva de la prisión, a efectos de limitar los sufrimientos innecesarios, mediante la supresión y/o minimización — dentro de ciertas posibilidadesde las divergencias entre la vida en el centro penitenciario y la vida exterior.

No obstante, la principal regla en relación al tema que se está analizando es la cuarta. En ella se manifiesta expresamente el objetivo que debe perseguir la pena privativa de libertad, que no puede ser otro que proteger a la sociedad del crimen y evitar la reincidencia. Expone el mismo párrafo de las Reglas Mandela que estas pretensiones sólo

\footnotetext{
124 TINEDO FERNÁNDEZ (2008), pp. 39-42.

${ }^{125}$ Habría que tener en cuenta en este sentido que también el gasto social o el nivel alcanzado por el Estado social en un determinado territorio influirá en el castigo, en el número de penados y, consecuentemente en su resocialización. De este modo, parece existir una comprobada relación entre un Estado social más avanzado y menores niveles de encarcelamiento. Véase, LARRAURI PIJOAN (2009), p. 8. Particularmente para el ámbito estadounidense, véase BECKETT y WESTERN (2001), pp. 43-59.

${ }^{126}$ MAPELLI CAFFARENA (2006), pp. 4-5.
} 
se pueden conseguir utilizando el tiempo en prisión para lograr "la reinserción de los exreclusos en la sociedad, tras su puesta en libertad, de modo que puedan vivir conforme a la ley".

Posteriormente, es dable destacar las Reglas 91 y 92, que se encargan de regular expresamente el "Tratamiento" y sus especificaciones. No obstante, unos preceptos anteriores se ocupan de los principios rectores de la vida en prisión para los condenados, entre los que se relaciona constantemente la menesterosidad de no separar al interno de la sociedad a la que se integrará tras el cumplimiento efectivo de su pena.

\section{2. Los fundamentos para el retorno a unas prisiones hijas de las sociedades de control}

A diferencia de lo que se viene comentando en el sub-epígrafe anterior, en las últimas décadas, de la misma manera, está sucediendo un fenómeno de signo contrario al anteriormente comentado, debido principalmente a la revolución que han supuesto las nuevas tecnologías, a la existencia de un mundo totalmente globalizado, a la facilidad en el intercambio y utilización de la información, y fundamentalmente, como consecuencia de los controles estatales que desde las autoridades gubernamentales se realizan constantemente, ante "supuestas" amenazas actuales -bajo el pretexto del mantenimiento del orden público o por razones de seguridad frente a actuaciones terroristas, que justifican cualquier actividad securitaria limitadora de los derechos fundamentales.

Todo ello ha provocado la eclosión de una especie de sociedades controladas a nivel estatal, en la que los gobiernos pretenden mantener inspeccionados a la amplia mayoría de los ciudadanos, ante eventuales ataques al sistema democrático, ${ }^{127}$ utilizando todos los procedimientos posibles, desde vigilancia telemática, en la red, videovigilancia, interceptación de las comunicaciones, etc., que bajo la argucia -como se ha dicho anteriormente- de lograr la protección de la ciudadanía. ${ }^{128}$

Como consecuencia de esta tendencia, es dable destacar que en España, hace unos años entró en vigor la Ley Orgánica 1/2015, de 30 de marzo, por la que se modificó el Código Penal, e instauró en relación a la ejecución de las penas, una medida nacida de la ideología del control, al efecto de perpetuar el internamiento de un sujeto bajo la argucia de controlar a un individuo potencialmente peligroso. Se trata de la institución de la prisión permanente revisable. Ésta limita enormemente las posibilidades de acogerse a la clasificación del penado al tercer grado penitenciario, hasta que no hubiese cumplido casi la totalidad de la pena, e incluso se le impide disfrutar de los permisos de salida. ${ }^{129}$ Por su parte, también se puede mencionar la Reforma del mismo Código por Ley Orgánica $5 / 2010$, que incluía en el régimen de ejecución penal de los individuos adultos una medida de seguridad post penitenciaria — más allá del ya cumplimiento total de la condena-, como es la libertad vigilada. Esta medida, en realidad, contempla la imposición de cualquier medida de seguridad, todas amparadas bajo tal institución, ${ }^{130}$ frente al sujeto

\footnotetext{
${ }^{127}$ Piénsese en los sucesos del 11-S, el 11-M, los atentados de Londres o París.

${ }^{128}$ ESTRADA CUZCANO (2005), pp. 150-161.

${ }^{129}$ Por tanto, es evidente que la pena permanente revisable y sus medidas chocan plenamente con las bases y principios de la reinserción social, máxime cuando con dicha medida se pretende neutralizar al delincuente, alejándolo el mayor tiempo posible de la sociedad.

${ }^{130}$ Véase el art. 106 del Código Penal español. Sería aplicable a todos los crímenes relativos a los delitos contra la vida, los relativos a las lesiones, en determinadas circunstancias a los delitos que acaecen en el ámbito doméstico, a los delitos de terrorismo y, por vía jurisprudencial, "a todos" los delincuentes por
} 
supuestamente peligroso. Así, el condenado tras años de reclusión, vuelve a ser supervisado en todas sus actividades, se le controla su libertad ambulatoria - incluso su salud - aun cuando el penado haya cumplido totalmente con su pena impuesta judicialmente. $^{131}$

Ahora bien, esta tendencia de trasfondo hacia el control, nunca dejó de existir, toda vez que siempre interesó a los gobiernos del mundo controlar a las clases sociales más bajas, puesto que el capitalismo intentó desde sus inicios eliminar a los pobre del sistema, mediante su ocultamiento, esto es, mediante su invisibilidad, por medio de una política criminal que punitiviza al delincuente más débil, más vulnerable —al estilo de lo comentado anteriormente, en el párrafo anterior-, que muestra una tolerancia cero o una intolerancia selectiva ante el crimen callejero, ante la delincuencia de los más desvalidos. ${ }^{132}$ De este modo, la desigualdad económica pasó a ser un problema de criminalidad, construyéndose las denominadas "Cárceles de la Miseria" para recluir y hacer desaparecer en el sistema penal y carcelario a estos "parias urbanos". ${ }^{133}$

\section{La arquitectura penitenciaria de la actualidad}

\section{1. Las nuevas tendencias en torno a la reinserción}

Para lograr el objetivo de rehabilitar absolutamente al preso y eliminar a su vez las secuelas adversas que conlleva normalmente aparejada la sanción penal consistente en la privación de libertad en una institución penitenciaria, han surgido arquetipos, infraestructuras o formas edilicias, que aun tratándose de centros de reclusión de los individuos, intentan neutralizar o al menos minimizar, esos efectos contraproducentes para los internos. ${ }^{134}$

Por tanto, para cumplir con mencionada finalidad, la cárcel se proyecta como si fuera un edificio público, un parque, un museo o una biblioteca, y no como un lugar siniestro, triste, apagado y vetusto. Y ello se debe a que tras unos dieciocho mil años de civilización, se presenta el presidio como el lugar donde se priva a una persona de libertad, pero sólo de su capacidad para decidir adonde ir, esto es, de sus movimientos, de su circulación, en definitiva, de su libertad, ni más ni menos. Por ende, no existen motivos adicionales que

\footnotetext{
delitos sexuales, puesto que el 192. 1 del CP español, permitió la no imposición para delitos menos graves realizados por autores primarios -STS 756/2014, de 11 de noviembre-.

${ }^{131}$ Para no dilatarse mucho en la exposición de estas ideas, se debe decir que de forma similar ha ocurrido en otros países del mundo como en la región latinoamericana, como por ejemplo, con las Leyes Blumberg en Argentina.

132 Baste recordar que en Estados Unidos en el Siglo XIX se decía que "un buen indio era un indio muerto". Vid. MIEDER (2001), p. 49.

133 Política estadounidense de la década de los ochenta y noventa del pasado siglo, que justificaron las prisiones hijas del control, y que rápidamente se extendió por el resto del mundo, tanto en Europa, como en países del segundo mundo, como Brasil o Argentina. Véase, WACQUANT (2006), pp. 60-61. Este hecho ha sido evidenciado en Europa Suroccidental respecto de la población inmigrante. En este sentido, véase MELOSSI (2005), pp. 5-21. Para el caso español es interesante estudiar el análisis correlacional entre la marcha de la economía y la dimensión de la población reclusa -específicamente respecto la población inmigrante-, así como la manifiesta criminalización y utilización de las teorías del etiquetamiento por parte de los agentes del sistema penal español. Véase, RUIZ-MORALES (2008), pp. 403-490.

${ }^{134}$ De hecho, se ha comprobado que los internos alojados en prisiones tipo campus presentan una mejor relación y comunicación con los oficiales de la prisión que aquellos con diseños estructurales más distanciados con el recluso, como es el caso del panóptico o los modelos radiales. Véase, BEIJERSBERGEN et al. (2014), p. 868-869.
} 
justifiquen confinar a los reos en establecimientos insalubres o rotundos, que le impidan además ejercitar el resto de sus derechos, puesto que ello sería añadir una pena supletoria a la verdaderamente impuesta.

Además, desde hace ya más de medio siglo se reclamaba un sistema penitenciario que contase con prisiones pequeñas - para alrededor de unas trescientas personas-, distribuidas por el territorio nacional de manera tal que estuvieran cerca de los lugares de origen de sus internos. ${ }^{135}$

Dentro de esta tipología de estructuras penitenciarias, cronológicamente apareció la prisión de Leoben o Justice Center Leoben (2004), en Austria. Este edificio no se asemeja en nada a una prisión y esa era la pretensión inicial, puesto que de este modo, el recluso no tiene la sensación de encierro - sino parece que aún se halla en libertad-mejorándose más que de una forma notable la resocialización del penado. El diseño se basa en las premisas del sistema penitenciario austriaco, el cual se fundamenta en que la mejor forma de reinsertar o reformar al delincuente es que éste permanezca en contacto con la sociedad, en vez de enclaustrarlo en lugar alguno ${ }^{136}$. Ahora bien, si dicha reclusión es menester, se hará en un lugar que lo menos que debe recordar es a un lugar de punición, ya que la resocialización no se sostiene por medio del recuerdo o escarmiento. Como símbolo de lo que se viene argumentando, la propia institución de Leoben rotula en una de sus paredes: "Todos los seres humanos nacen libres e iguales, con dignidad y derechos".

Arquitectónicamente, ${ }^{137}$ la fachada exterior principal es íntegramente de cristal, para que el sol inunde de luz natural el centro durante el día. Igualmente, las habitaciones y las estancias comunes son bastante luminosas. Durante la noche se utiliza la luz eléctrica para otorgar claridad al lugar. La prisión posee un novedoso sistema de ventilación y espacios reservados para el ocio: desde spa, gimnasio, zona de televisión y de juegos, biblioteca, capilla, hilo musical. Las celdas con inodoro y ducha propias, están amuebladas y poseen vistas panorámicas al exterior $-\mathrm{o}$ al menos parcialmente, pueden ver el cielo y parte de la ciudad - . Se permite la libertad de movimientos de los reclusos por toda la prisión, pudiendo accederse libremente a los espacios que también posee al aire libre. Ahora bien, durante su estancia los internos deben trabajar remuneradamente, no obstante, si no conocieran oficio, durante su encierro reciben la educación que se requiera para adquirir formación profesional.

Como resultado, los conflictos y los actos de destrucción o vandalismo se han disminuido drásticamente en comparación con otras cárceles austriacas, disfrutándose de un clima sosegado y tranquilo entre presos, y entre éstos y los funcionarios.

En segundo término, aparece la cárcel de Handel Fengsel ${ }^{138}$ (2010), Noruega, que es considerada una de las prisiones más humanas del mundo a pesar de ser de máxima

\footnotetext{
${ }^{135}$ Esta política penitenciaria sería más idónea que la de construir grandes complejos y establecimientos penitenciarios, con los altos costes de construcción y mantenimiento de las mismas. Véase, LÓPEZ REY Y ARROYO (1962), passim.

${ }^{136}$ LEWIS (2009), pp. 14-23.

137 Véase la Figura 17 -Anexos-.

138 Véase la Figura 18 -Anexos-.
} 
seguridad. ${ }^{139}$ En el país nórdico siguen unos criterios penitenciarios muy similares a los que se mencionaron para el caso austríaco, de este modo, las prisiones noruegas intentan que el preso se adapte lo mejor posible a la misma, para que cuando vuelva a la sociedad esté totalmente recuperado. Para ello, los funcionarios deben someterse a una preparación académica durante dos años, para conseguir capacidades y habilidades específicas que motiven la rehabilitación de los internos —algunos reclusos requieren de habilitación y no de rehabilitación, ya que nunca han recibido antes ningún tipo de educación-, participando y realizando las actividades diarias con los reclusos, como el almuerzo o interactuando con ellos durante espacio temporal con el que cuentan para hacer deporte, mezclándose con ellos y resolviendo problemas in situ como un trabajador social sin portar arma alguna -esto es, de acuerdo a los postulados de la "seguridad dinámica"-. Además, la mitad del cuerpo de agentes son mujeres, puesto que se mejora de esta manera la conducta y elimina la tensión de los sujetos encerrados. ${ }^{140}$

El presidio cuenta con doscientos doce dormitorios individuales, con baños totalmente alicatados, nevera y televisor de pantalla plana. Cada decena de celdas posee una cocina y sala de estar para la relajación y distracción, tras el día de trabajo, y en ningún lugar existen barrotes. Además, el presidio sólo se encuentra rodeado por una muralla perimetral de unos escasamente dos metros.

Por otra parte, para facilitar la adaptación y su posterior reinserción social, así como disminuir la presión ambiental, se decoraron los muros de la prisión, se pintaron las salas interiores de distintos colores - dependiendo de la funcionalidad que se persiga-, y se mantuvo la vegetación original del lugar, pareciendo permanecer en una estancia en el bosque.

Los presos tienen ocupadas doce horas al día, desde las ocho de la mañana a las ocho de la noche, bien trabajando, bien en actividades lúdicas y deportivas, o en actividades educativas para acostumbrarlos a una habitualidad para su posterior salida de prisión, y asimismo, reducir las probabilidades de ataques al personal. ${ }^{141}$

Otro ejemplo de esta nueva arquitectura es la prisión danesa de máxima seguridad de Storstrøm en la Isla de Falster, cuya apertura estaba prevista para el año 2016, pero que se abrió en septiembre de 2017. Esta prisión cuenta con los fundamentos básicos de la arquitectura penitenciaria de Cuarta Generación, toda vez que acoge tales principios ${ }^{142}$.

\footnotetext{
${ }^{139}$ Algunos autores entienden que dicha prisión no es más que una prisión de exhibición, ya que la estructura arquitectónica no cumple con la labor ideada, puesto que posteriormente la realidad carcelaria modifica su funcionamiento. Véase, GILLESPIE (2010), p. 46.

${ }^{140}$ Ahora bien, la prisión cuenta con más empleados que presos -algo lógico si se quiere cumplir con la exigencia de control, tutorización, rehabilitación-, al objeto de restringir la reincidencia.

141 BENEZIC (2016), passim.

${ }^{142}$ Las bases de la cuarta generación de la arquitectura penitenciaria son, a grandes rasgos: 1. El espacio carcelario debe tener en cuenta las necesidades de Maslow, estableciendo un ambiente humanizado. Debe ampararse con la construcción el carácter afectivo -dentro de lo posible-, favoreciéndose las relaciones personales y la privacidad de los reclusos. 2. Debe contarse con programas formativos, laborales, sociales, culturales, educacionales, espirituales, que se potencian con el propio recinto, el cual debe ser altamente luminoso y ventilado, limpio, saludable, térmicamente adaptado, construido con materiales naturales, y decorado estimulantemente con colores propicios, que enlace fácilmente con la naturaleza. 3. Para facilitar la emotividad, deben estar equipados con espacios familiares, con materiales y juegos para niños, para las visitas, favoreciéndose así la afectividad. 4. Los espacios deben propiciar la realización de actividades, ya sean pasivas, deportivas, artísticas, etc. 5. La prisión debe desenvolverse con una trama urbana, de edificios, espacios abiertos, cerrados y semicerrados, con calles, plazas, jardines, barrios, etc. 6. La muralla perimetral
} 
Se debe decir que se trata de una cárcel que dispone fundamentalmente de edificios bajos y con una trama urbana, ${ }^{143}$ contando con calles dentro del propio recinto amurallado donde se sitúan módulos radiales que funcionan como dormitorios, y las instalaciones de trabajo y ocio ${ }^{144}$ en derredor de una edificación cuadrada central. ${ }^{145}$ Por lo tanto, crea un clima especialmente favorable a la rehabilitación, ${ }^{146}$ porque dentro de los límites perimetrales se hallan tipos diversos de espacios, como el rural - agrícola y ganadero, el paisajístico y el urbano, a modo de casco nuclear de una ciudad, por lo que recrea un entorno ameno y variado al estilo propio de una verdadera ciudad, es decir, reproduciendo una pequeña comunidad urbana.

En el centro de la prisión está el eje cultural de la penitenciaría, como la biblioteca y el centro educativo que se materializa en una edificación singular al resto, pero con predominante uso del vidrio en vez de hormigón. A partir de ahí se ubican la iglesia, la tienda y las dotaciones deportivas, y en un lugar más alejado los módulos en forma de estrella donde se alojan los reclusos en habitaciones altamente iluminadas naturalmente con dos grandes ventanales, gozando así de distingas vistas, aun cuando ya tienen excelente privacidad, la cual se ve reforzada por la disposición de las ventanas, de manera que no se ven los unos a los otros. ${ }^{147}$ Por tanto, parece que se trata de un lugar idóneo para la reinserción del sujeto, motivo por el cual no se trata de un establecimiento usual, por lo que se considera la prisión más humana del mundo. ${ }^{148}$

Por último, para terminar con la senda de estas nuevas tendencias reinsertadoras, es menester aludir a una prisión que si bien no es la de más reciente construcción, parece ser que fue la más revolucionaria en la materia, toda vez que recientemente cumplirá cuatro décadas. Se trata de la prisión de la Isla de Bastoy (1982), en Noruega. Se trata de un "presidio" donde los internos viven casi en total libertad — dentro de la isla--, ya que disponen hasta de las llaves de sus bungalows de madera, no existen los guardias armados — además de ser un escaso número- y es como si fueran habitantes libres de esa pequeña isla, en la que deben trabajar y estudiar, para mantenerla autosuficientemente en la medida de lo posible ${ }^{149}$.

Es evidente, que en un centro como éste, la pena de prisión se considera puramente rehabilitación y no un castigo, de ahí las cifras de reincidencia que posee. Sólo dieciseis

\footnotetext{
debe introducir elementos trasparentes, que permitan divisar el exterior, ya que la contención se consigue con medios electrónicos, no mediante un cercado propio de una fortaleza. Véase, GARCÍA BASALO (2018), pp. 10-13. No obstante, otros autores consideran que esta modalidad arquitectónica no es más que una nueva forma de control, toda vez que estas prisiones pueden provocar malestares, molestias o trastornos nuevos en los internos, desde el punto de vista de la organización crítica. Véase, HANCOCK y SPICER (2010), pp. 96-100.

143 Véase la Figura 19 -Anexos-.

${ }^{144}$ Se le da una importancia vital al deporte, por su relación con el ánimo y la disciplina.

145 ZULETA (2011), passim.

${ }^{146}$ Se elimina el concepto de que el interno está sufriendo una pena que institucionaliza y priva al sujeto de identidad, sino que esta prisión -por el contrario- se asienta en la flexibilidad, en la variedad y en la expresión personal.

${ }^{147}$ Se revoluciona el concepto de celda, ya que se estructura con una pared curva, facilitando las labores de vigilancia desde fuera de la misma, a la vez que se permite personalizar este espacio.

${ }^{148}$ La prisión de Halden, respecto a esta, humaniza a través del personal. En cambio, esta prisión situada en Falster, intenta humanizar a través de la arquitectura. Para mayor información, fotos y planos, véase https://www.floornature.es/c-f-moller-architects-carcel-de-storstrom-en-dinamarca-13439/ [visitado el 08/07/2020].

149 JAMES (2013), passim.
} 
de cada cien reclusos que pasan por la Isla de Bastoy vuelven a delinquir, lo que enmarca a las claras que este es el modelo penitenciario a seguir ${ }^{150}$.

\section{2. La aplicación de los nuevos medios de control}

Como se comentó anteriormente, desde finales de los años setenta y principios de los ochenta, comenzó a utilizarse en la infraestructura presidiaria una "Nueva Generación" de arquetipos, que en realidad era un sistema heredero de las aportaciones de Bentham. Esta configuración arquitectónica fue conocida como Diseño Podular penitenciario, que se utilizó en el interior de los Complejos Penitenciarios para organizar la estructura modular.

Este diseño consiste en organizar la unidad funcional, en el que conviven unas treinta o cuarenta personas, de una manera tal que las celdillas o dormitorios se dispongan en derredor del puesto de control, adquiriendo el módulo penitenciario una forma cuasi triangular. Ahora bien, si la vigilancia se hace desde el exterior y separadamente de la unidad, se realizaría mediante "Observación Remota"151; en cambio, si el vigilante se integra y controla desde el interior de la unidad, se habla de "Supervisión Directa ${ }^{152 "}$ ".

Es destacable, antes de finalizar, añadir una mención a las posibilidades de vigilancia que ofrecen hoy día los sistemas tecnológicos actuales, mediante video, sensores, señal GPS, etc., lo que puede redundar en un abaratamiento de costes de personal de las prisiones, puesto que, por medio de estos instrumentos, se puede supervisar sin necesidad de gran cantidad de recursos humanos. Sin embargo, también hay que advertir, como ya se hizo ad supra, sobre la indudable vulneración de los Derechos Humanos que se producen cuando se utilizan estas técnicas, afectando esencialmente a la intimidad, privacidad y dignidad del recluso, que aunque interno, sigue siendo portador de todos los Derechos Humanos, a excepción de la libertad ambulatoria.

De acuerdo a las premisas de base, otras prisiones se caracterizan por utilizar los novedosos mecanismos de control hasta las últimas consecuencias, de una forma sistemática. En ellas, a diferencia de las prisiones más humanas y resocializadoras, lo que prima es la seguridad, ${ }^{153}$ esto es, que el sujeto no pueda escapar de ninguna manera, y se hará todo lo posible para lograr tal objetivo. De esta forma, la vulneración de derechos fundamentales de los reclusos — como la intimidad o la privacidad - es constante, ya que estos derechos no son bienes jurídicos objetos de consideración en estas cárceles, toda vez que el interno es un delincuente, y se les puede desprender de parte de sus derechos. Ante tal situación, es totalmente normal que en estas penitenciarías la preocupación en torno a la reinserción del individuo sea nimia o, simplemente, nula. Esta situación de claro retroceso de los avances desarrollados a lo largo de los últimos ciento cincuenta años, tiene un gran número de adeptos, entre los que se encuentran muchos gobiernos que se

\footnotetext{
150 JAMES (2013), passim.

${ }^{151}$ Véase la Figura 20 -Anexos-. Este modelo es utilizado por el Complejo Penitenciario de Ezeiza, tanto a nivel de Unidad Funcional, como para el conjunto de Módulos o Complejo, como se puede observar en la Figura 16, por medio de los colores amarillo y rojo.

${ }^{152}$ Véase la Figura 21 -Anexos-. En este caso, el vigilante se integra con los reclusos, por lo que puede "humanizar" al recluso un poco más que la observación remota.

${ }^{153}$ Es como que el interno debe sentirse sometido al castigo, como represalia por el delito. De este modo, se vuelven a postulados vigentes hace varios siglos, aunque ejecutados con los medios tecnológicos de la actualidad.
} 
llaman a sí mismos democráticos, cuando en realidad, no garantizan libertades y derechos elementales para la persona privada de libertad. ${ }^{154}$

Un problema que se viene observando en las últimas décadas es que muchas de las prisiones están construidas y diseñadas para albergar a presos de máxima seguridad ${ }^{155}$ se trata de prisiones de máxima seguridad, valga la redundancia-, no obstante, los internos que son albergados en ellas no son en su mayoría reclusos de dicha tipología, por lo tanto, estas personas son sometidas a unas medidas más gravosas que las necesarias para él, siendo que este aspecto perjudica enormemente las posibilidades de rehabilitación y bienestar de dichos penados. ${ }^{156}$

Como antecedente de este modelo, durante la década de los setenta en Estados Unidos, aparece en el panorama de la arquitectura carcelaria la designada "Nueva Generación", en el Centro Correccional Metropolitano de Chicago (1975). ${ }^{157}$ En este Centro Penitenciario los módulos se diseñan en base a un espacio común y multiusos en torno al cual se sitúan las celdas y los servicios de apoyo, ${ }^{158}$ para que los presos disfruten en él de su jornada diurna, llevándose a cabo la "supervisión directa" con el agente supervisor dentro del propio salón. Se caracteriza por materializarse en una planta triangular, que permite la inspección sin barreras físicas, forma básica del sistema podular. ${ }^{159}$

No obstante, siguiendo el recorrido cronológico de las tesis del control, se puede mencionar primeramente el Centro Souza Baranowski (1998), en Massachusetts, Estados Unidos. Se trata de una pequeña prisión tecnológica, puesto que ella opera como un verdadero "Gran Hermano", al existir en esta cárcel alrededor de cuatrocientas cámaras que graban las veinticuatro horas del día. Igualmente, cuenta con sensores alrededor del edificio para identificar eventuales movimientos a través de microondas y cables tensados. Posee el sistema de vigilancia más potente del mundo, desarrollado al efecto por el Instituto Tecnológico de Massachusetts, con soporte en cuarenta y dos ordenadores, que permiten el control de puertas, luces, recipientes, intercomunicación, sin necesidad de utilizar ninguna llave. ${ }^{160}$

Un poco más reciente es la Penitenciaría de Terre Haute (2004) en Indiana, Estados Unidos. Esta prisión cuenta con el mayor sistema de seguridad electrónica. Para ello se utilizan cámaras, sensores de movimiento, tecnología de reconocimiento facial para identificar a cada interno, así como el uso en las celdas del candado biométrico. Diametralmente, se vigila a través de seis torres de control externas, más una situada en

\footnotetext{
154 SAINATO (2019).

155 Algunos autores sostienen que el modelo panoptista -cuyo fin del castigo es retributivo- sigue consolidado en el sistema estadounidense de prisiones -en el que la mayoría de las mismas son de máxima seguridad-, y aunque se califican de "modernas y austeras", en realidad se fundamentan en el aislamiento y en la exclusión. Véase, ARIZA y ITURRALDE (2016), pp. 25-26.

${ }^{156}$ MATTER ARCHITECTURE (2017), pp. 12-19.

157 Véase la Figura 22 -Anexos-.

${ }^{158}$ Aunque el diseño parece novedoso y revolucionario, no nos debe resultar original e innovador, en tanto en cuanto se recuerde la disposición edilicia de la Maison de Force o Correccional de Gante, cuyas celdas se construyeron en torno a un patio central de forma octogonal, con la finalidad de favorecer la vigilancia desde aquel.

${ }^{159}$ BRUNO (2006), pp. 13-15.

${ }^{160}$ Disponible en la web del gobierno de Massachusetts, en: http://www.mass.gov/eopss/law-enforce-andcj/prisons/doc-facilities/souza-baranowski-correctional-center.html [visitado el 08/07/2020].
} 
el centro del complejo, con módulos de apariencia triangular, en los cuales se puede aplicar el diseño podular $^{161}$.

A mayor abundamiento, existen otras prisiones de características similares, que además de utilizar los medios electrónicos, también hacen uso de innumerables métodos. En algunas optan por enclaustrar a los reclusos, en otras por incorporar gran número de vigilantes. Ahora bien, también existen infinidad de casos en los que se prefiere instaurar mecanismos actuales en prisiones relativamente antiguas, como ocurre en la prisión de La Santé, situada en el centro de París, mejorando, de este modo, las labores de vigilancia y haciendo de dichas cárceles un lugar absolutamente inquebrantable.

\section{Conclusiones: la necesaria reinserción}

En el presente artículo se ha demostrado cómo las tesis sobre la forma de hacer justicia, sobre cómo debe ser el castigo, determinó la naturaleza de éste y, a partir de la Ilustración, también delimitó las estructuras que debían poseer los edificios dedicados al encierro al colocarse como forma de castigo predominante-, esto es, definió los aspectos fundamentales de la arquitectura penitenciaria.

Por tanto, la evolución en el entendimiento de cómo castigar, provocó, una especie de relación causa-efecto ${ }^{162}$ en constante proceso de cambio en la construcción de las prisiones, incorporando novísimos métodos, infraestructuras y modelos, que se hacían eco de las vanguardistas ideas sobre el desarrollo de la pena privativa de libertad.

Además, en este trabajo ha quedado plasmado de una manera subyacente, un hecho típico de la arquitectura penitenciaria, consistente en que esta rama de la proyección de edificios siempre va unos años atrás de las tendencias ideológicas aportadas por los grandes penalistas de todos los tiempos, que causaron y causarán avances en esta parcela jurídica. Igualmente, en el mismo orden de cosas, se debe añadir que muchas veces, la consolidación de esos modelos penitenciarios novedosos se demora varias décadas, e incluso a veces se siguen edificando centros penitenciarios bajo las premisas de teorías del castigo superadas o caducas.

Otro aspecto mostrado en este artículo es que contemporáneamente, en los distintos países, conviven diferentes maneras de hacer justicia y, por ende, existen diversos niveles de actualización de la arquitectura penitenciaria que dependen del lugar. La manera de entender el castigo es fruto principalmente de la sociedad, del nivel cultural de la población, de los ciudadanos, de la cultura del país, de los valores del grupo social, de los estándares de delincuencia, de las tasas de criminalidad, la situación social, política y económica, etc., por lo que habrá países que se hallan en los primeros estadios en lo que respecta al modo de castigar, por ejemplo, los países árabes en los que la pena de muerte - lapidación-—con escarmiento público está permitido; mientras que otros se encuentran en niveles de desarrollo social mucho mayor, valorando la resocialización sin discusión y preocupándose por las consecuencias negativas del encierro, como ocurre en los países

\footnotetext{
161 Véase la Figura 23 -Anexos-.

${ }^{162}$ A pesar de que a veces la intención pretendida en el diseño arquitectónico no se cumple en la cotidianidad de la prisión, máxime si se tiene en cuenta que el arquitecto que idea el edificio se relaciona con un Ministerio estatal, o con una empresa, pero no con el funcionario de prisión o agente oficial que trabajará en el interior de la prisión, que sería su verdadero "usuario final". Véase, HANCOCK y JEWKES (2011), pp. 611-629, p. 623.
} 
nórdicos en los que la arquitectura penitenciaria intenta depurar esos efectos nocivos en la rehabilitación del penado. Entre medias están la mayoría de países del mundo, en esa zona grisácea, máxime cuando pueden permanecer abiertas y vigentes cárceles que ostentan distingas plantas en el interior de un mismo Estado. ${ }^{163}$

A mayor abundamiento, a partir de la experiencia noruega en la Isla de Bastoy, se puede aventurar, a modo de corolario, como deberá ser la evolución de la estructura presidiaria que se proyectará en el futuro.

Pues bien, como se analizó anteriormente, la característica primordial de la prisión isleña de Bastoy, es que se asemeja a lo que sería una sociedad. Ahora bien, aun cuando en el particular caso insular se trate de una verdadera recreación de una sociedad independiente y autónoma del resto de miembros del grupo social, se puede entrever que los derroteros de esa ciencia edificativa deberán ir en tal dirección, como se puede observar en Leoben, Halden o Falster.

Y es que la base fundamental de ese cambio de paradigma se debe a la variación en la interpretación de lo que debe ser el castigo, toda vez que actualmente la sanción jurídicopenal consistente en la privación de libertad tiene que cumplir con la misión de educar al individuo para acomodarlo a la vida en sociedad, y no con ejercer un control sin paliativos. Por esa razón, se va más allá del simple y tradicional encierro.

Por este motivo, se crea en Noruega una comunidad ad hoc paralela a la sociedad real, pero que actuará de forma similar a la misma, y que conseguirá cumplir con la función penal. Esto presenta una lógica aplastante. Si hoy en día la funcionalidad del castigo, su última ratio debe ser resocialización y reeducación del penado, ergo las prisiones deberán ser un reflejo absoluto de la realidad social a la que el sujeto posteriormente se reintegrará, de ahí que el interno deba cumplir su pena privativa de libertad en una recreación fidedigna de la sociedad, o incluso en la sociedad misma.

Es así: las innovadoras tesis en torno al castigo hablan de la "nueva socialización" del reo, eliminando los efectos perjudiciales del castigo. Pues bien, si no hay más remedio que privar a un individuo de libertad, el sujeto no puede ser libre para ir y hacer lo que le apetezca; ahora bien, es únicamente eso, pero no más. Es irrestrictamente contradictorio que para sociabilizar a un individuo conforme a unos estándares sociales, se le constriñan multitud de otras de sus libertades y derechos, y se le impongan multitud de restricciones que lo alejan de su esencia social.

De este modo, es lógico que muchos intelectuales en materia penal hablen de la "sociabilización contrarrestando a la pena", toda vez que el cumplimiento de la pena de prisión en un establecimiento penitenciario crea efectos adversos en la sociabilidad del sujeto delincuente, que van desde la institucionalización del individuo que deja de saber vivir en la comunidad, hasta aspectos tales como la quiebra y rotura del vínculo familiar

\footnotetext{
${ }^{163}$ España -por ejemplo- mantenía abiertos hace unos años instituciones penitenciarias fe muy diferente concepción y finalidad punitiva. Por un lado, estaba la Cárcel Modelo de Barcelona amparada en el modelo radial. Por otro lado, abrían sus puertas multitud de Centros Penitenciarios Tipo -como el Centro Penitenciario de Puerto III-. Sin embargo, la mezcolanza era total con otros Complejos Penitenciarios de diversa estructura dependiendo del lugar - como es el caso de Puerto I o Puerto II-.
} 
y grupal al separar al condenado de su lugar, lo que provocará un impacto en su personalidad, en su carácter y en sus sentimientos futuros.

Por esta razón, se podía plantear el siguiente símil: si se necesita o quiere dinero, las personas acudimos a una institución financiera, que recibe el nombre de banco, y que es lugar donde obtener dinero en base a ciertas condiciones. Por otra parte, al que se quiere educar o necesita de educación se le manda a una institución educativa, que se llama colegio o instituto dependiendo del nivel educativo, mas en todo caso será el lugar que ofrecerá educación a personas. Otro ejemplo, si a un sujeto se le quiere curar o necesita de curación, se le manda a una institución sanadora, que se denomina nosocomio u hospital, y donde hay profesionales que se dedican al restablecimiento de la salud.

Por ello, se debe plantear que si al penado se le quiere socializar o necesita de sociabilización, ¿No habría que acercarlo a la sociedad para que el individuo recupere el respeto a las normas grupales de la comunidad? Entonces, ¿Por qué se hace justamente lo contrario?

Siguiendo la senda iniciada en los países nórdicos, el futuro de las prisiones no puede ser otro que su desaparición, ya que no tiene sentido en la reeducación y la reinserción social aislar al sujeto y separar del condenado de la entidad medular que ofrece esos principios de convivencia.

¿No tendría más sentido limitar la libertad para paliar su falta de sociabilidad, ya que su libertad deambulatoria está restringida? Sin embargo, se le impregna de altas dosis de esa cualidad social, ergo, ¿No sería más interesante y fructífero situar al sujeto en un lugar en constante interacción con multitud de personas diversas, que le ofrezcan nuevas perspectivas, le "abran" la mente, le incorporen diversos planos o perspectivas distingas de las que posee, dependiendo del delito cometido?

Así debe ser. La solución no pasa por sociabilizar entre personas que piensan igual, que comparten las mismas ideas o mismas experiencias vitales, toda vez que por este motivo - al estar integrado en ese grupo social inicial con unas posturas arraigadas ${ }^{164}$ — le falló a la comunidad y delinquió, fracasando así los medios de control social. Por ende, el día de mañana la resocialización se hará en la propia sociedad —obviamente recortando la libertad de circulación del condenado - donde se le brindará a los delincuentes unos valores y normas sociales a través de la demostración de los mismos en la propia vida en sociedad.

\footnotetext{
${ }^{164}$ Téngase en cuenta la Teoría de la Asociación Diferencial de Sutherland. Vid. SUTHERLAND (1947).
} 


\section{Bibliografía}

ALTMANN SMYTHE, Julio (1970): “Arquitectura penitenciaria”, en: Derecho PUCP $\left(n^{\circ} 28\right)$, pp. 56-77.

ANITUA, Gabriel Ignacio (2004): Contradicciones y dificultades de las teorías del castigo en el pensamiento de la Ilustración, en: RIVERA BEIRAS, Iñaki (Coord.), Mitologías y discursos sobre el castigo. Historias del presente y posibles escenarios (Rubí: Anthropos).

ARIZA, Libardo José y ITURRALDE, Manuel (2016): "La prisión como espacio de exclusión o reconciliación", Dearq (n 18), pp. 20-31.

BADARÓ BAPTISTA, Tatiana María (2015): "A solidão como pena: uma análise dos sistemas penitenciários filadélfico e auburniano", en Revista do CAAP (n 1 (21)), pp. 77-92.

BARATTA, Alessandro (1999): Reintegración Social del detenido. Redefinición de concepto y elementos de operacionalización, en: MARTÍNEZ SÁNCHEZ, Mauricio; BARATTA, Alessandro; FERRAJOLI, Luigi y IBÁÑEZ, Perfecto Andrés, La pena, Garantismo y Democracia (Santa Fe de Bogotá: Ediciones Jurídicas), pp. 67-88.

BECCARIA, Cesare (1969): De los delitos y las penas (Madrid: Aguilar).

BECKETT, Katherine; WESTERN, Bruce (2001): "Governing Social Marginality: Welfare, Incarceration, and the Transformation of State Policy", en: Punishment \& Society $\left(n^{\circ} 3(1)\right)$, pp. 43-59.

BEIJERSBERGEN, Karin; DIRKZWAGER, Anja; VAN DER LAAN, Peter; NIEUWBEERTA, Paul (2014): “A social building? Prison Architecture and StaffPrisoner Relationships", en: Crime and Delinquency (nº 62 (7)), pp. 843-474.

BENEZIC, Dollores (2016): "Un tour por Halden, la cárcel más humana del mundo", Liberties (30/12/2016). Disponible en: https://www.liberties.eu/es/news/haldenla-carcel-mas-humana-del-mundo/11078 [visitado el 30.01.2019].

BENTHAM, Jeremy (1839): Compendio de los Tratados de legislación civil y penal (Madrid: Vda. De Calleja e Hijos).

BERGALLI, Roberto (1999): Hacia una cultura de la jurisdicción. Ideología de jueces y fiscales (Argentina - Colombia - Italia - España) (Buenos Aires: Ad Hoc).

BRUNO, Carlos (2006): "Evolución histórica de las construcciones penales en Argentina", en: Congreso de Arquitectura Penitenciaria (Octubre de 2006).

CADALSO, Fernando (1913): Instituciones penitenciarias en Estados Unidos (Madrid: Biblioteca hispánica).

CARO POZO, Felipe (2011): “Arquitectura penitenciaria: desde su génesis a las nuevas tecnologías de investigación criminal”, en: Crítica, Revista Latinoamericana de Ensayo (09/09/2011). Disponible en: http://critica.cl/otros/arquitecturapenitenciaria-desde-su-genesis-a-las-nuevas-tecnologias-de-investigacioncriminal [visitado el 30.01.2019].

CARO POZO, Felipe (2013): "John Howard y su influencia en la reforma carcelaria europea de finales del Siglo XVIII", en: Eguzkilore: Cuaderno del Instituto Vasco de Criminología (nº 27, año 2013), pp. 149-168.

CASTRO, Benigno (2007): Historia de las cárceles leonesas. Memoria de veinte siglos de encarcelamiento y arquitectura penitenciaria (León: Everest).

CONDE-PUMPIDO FERREIRO (1990): Cándido. Derecho Penal. Parte General (Madrid: Colex Editorial).

CUELLO CALÓN, Eugenio (1968): La moderna penalogía (Barcelona: Bosch). 
DE GIORGI, Alessandro (2016): "Hacia una economía post-fordista del castigo: la nueva penología como estrategia de control post-disciplinario", en: Delito y Sociedad $\left(n^{\circ} 27\right)$, pp. 45-71.

ECO, Umberto (1978): La estructura ausente (Barcelona: Lumen).

ELBERT, Carlos Alberto (2001): Manual básico de Criminología (Buenos Aires: Eudeba).

ESTRADA CUZCANO, Alonso (2005): "Internet: cambio social, libertad e intimidad", en: Escritura y Pensamiento ( $\left.{ }^{\circ} 16\right)$, pp. 149-162.

FALCÓN Y TELLA, María José; FALCÓN Y TELLA, Fernando (2005): Fundamento y finalidad de la sanción: ¿un derecho a castigar? (Madrid: Marcial Pons).

FERRAJOLI, Luigi (1998): Derecho y razón. Teoría del garantismo penal (Madrid: Trotta).

FLEW, Antony (1954): “The justification of punishment”, en: Philosophy (n⿳2 29), pp. 291-307.

FOUCAULT, Michel (1990): Vigilar y castigar (Madrid: Siglo XXI Editores).

FRAILE, Pedro (1987): Un espacio para castigar. La cárcel y la ciencia penitenciaria en España (siglos XVIII-XIX) (Barcelona: Ediciones del Serbal).

GARCÍA BASALO, Alejo (2002): "La arquitectura penitenciaria de nueva generación ¿Qué es la supervisión directa?", en: Revista de Estudios Criminológicos y Penitenciarios ( $\left.{ }^{\circ} 4\right)$, pp. 27-44.

GARCÍA BASALO, Alejo (2003): "Complejos penitenciarios. Alcance de la relación entre arquitectura y régimen penitenciario", en: Revista de Estudios Criminológicos y Penitenciarios ( $\mathrm{n}^{\mathrm{o}}$ 6), pp. 59-91.

GARCÍA BASALO, Alejo (2006): "La influencia chilena en la construcción del primer edificio penitenciario argentino", en: Revista de Estudios Criminológicos y Penitenciarios ( $n^{\circ}$ 9), pp. 113-154.

GARCÍA BASALO, Alejo; MITHIEUX, Mónica (2017): Para seguridad y no para castigo. Origen y evolución de la arquitectura penitenciaria provincial argentina (1853-1922) (San Miguel de Tucumán: Universidad Nacional de Tucumán/ Ed. Humanitas/ INIHLEP).

GARCÍA BASALO, Alejo (2018): "La arquitectura penitenciaria de cuarta generación ¿pueden ser más humanas las prisiones?”, en: Revista Electrónica de Estudios Penales y de la Seguridad (n⿳3 3), pp. 1-22.

GARCÍA VALDÉS, Carlos (1986): "Derecho penitenciario militar: una aproximación histórica", en: Anuario de Derecho Penal y Ciencias Penales (n 39), pp. 771-836.

GARLAND, David (2001): The culture of control. Crime and social order in contemporary society (Oxford: Oxford University Press).

GARLAND, David (2006): Castigo y sociedad moderna. Un estudio de Teoría social (México, D. F.: Siglo XXI Editores).

GILLESPIE, Kelly (2010): "The social life of space: Post-apartheid prisons, and the problem with architectural reform", en: Prison Service Journal (n 187), pp. 4047.

GINZBURG, Carlo (2015): “Miedo, reverencia, terror: releer a Hobbes hoy", en: Apuntes de Investigación del CECYP (nº 26), pp. 30-49.

HANCOCK, Philip; SPICER, André (2010): "Academic architecture and the Constitution of the New Model Worker", en: Culture and Organization ( $\left.n^{\circ} 17(2)\right)$, pp. 91-105.

HANCOCK, Philip; JEWKES, Yvonne (2011): “Architectures of incarceration. The spatial pains of imprisonment”, en: Punishment and Society (nº 13 (5)), pp. 611629. 
JAMES, Erwin (2013): "The Norwegian prison where inmates are treated like people", en: The Guardian (25/02/2013). Disponible en: https://www.theguardian.com/society/2013/feb/25/norwegian-prison-inmatestreated-like-people [visitado el 30.01.2019].

JOHNSTON, Norman Bruce (1973): The human cage: A brief history of prisons architecture (Nueva York: Walker and Company).

LARRAURI PIJOAN, Elena (2009): "La economía política del castigo", en: Revista Electrónica de Ciencia Penal y Criminología (n $\left.{ }^{\circ} 11-6\right)$, pp. 1-22.

LEWIS, Jim (2009): "Una prisión de la que nadie quiere escapar”, en: Etiqueta Negra ( ${ }^{\circ}$ 18), pp. 14-23. Disponible en: http://www.elboomeran.com/upload/ficheros/noticias/inquilinos.pdf [visitado el 30.01.2019].

LÓPEZ, Marcial Antonio (1832): Descripción de los más célebres establecimientos penales de Europa y los Estados Unidos (Valencia: Imprenta de Don Benito Monfort).

LÓPEZ REY Y ARROYO, Manuel (1962): Some Aspects of the Institutional Treatment of Offenders (El Cairo: Mimeo).

MAPELLI CAFFARENA, Borja (2006): "Una nueva versión de las normas penitenciarias europeas", en: Reflexiones, Revista Electrónica de Ciencia Penal y Criminología (n $\left.{ }^{\circ} 8\right)$, pp. 1-44.

MARGARIÑOS, Néstor (2008): "Arquitectura y construcción de prisiones: Nuevas cárceles, viejos problemas", en: Encrucijadas (n 43), pp. 1-4. Disponible en: http://repositoriouba.sisbi.uba.ar/gsdl/collect/encruci/index/assoc/HWA_316.dir/ 316.PDF [visitado el 30.01.2019].

MARKUS, Thomas (1993): Buildings and power: Freedom and Control in the Origin of Modern Building Types (London: Routledge).

MATTER ARCHITECTURE (2017): Wellbeing in prison design. A guide (London: Innovate UK / RIBA). Disponible en: http://www.matterarchitecture.uk/wpcontent/uploads/2018/05/421-op-02_Design-toolkit-report-online.pdf [visitado el 15.06.2019].

MELOSSI, Darío; PAVARINI, Massimo (1980): Cárcel y fábrica: los orígenes del sistema penitenciario (Madrid: Siglo XXI Editores).

MELOSSI, Darío (2005): "Security, Social Control, Democracy and Migration within the 'Constitutions' of the EU', en: European Law Journal (n' 11), pp. 5-21.

MIEDER, Wolfgang (2001): "El mejor indio es un indio muerto. Sobre la internacionalización de un refrán americano", en: Paremia (nº 10), pp. 49-55.

MONTESQUIEU (1972): Del espíritu de las leyes (Madrid: Tecnos).

MOSQUEA GARCÍA, Serafina Mercedes (2019): Análisis del nuevo modelo de gestión penitenciaria de la República Dominicana, a la luz de la influencia del Modelo Penitenciario Español (Murcia: Universidad de Murcia).

MUÑAGORRI LAGUÍA, Ignacio (1977): Sanción penal y política criminal. Confrontación con la nueva defensa social (Madrid: Biblioteca Jurídica de Autores Españoles y Extranjeros).

PAIVA, Miguel Ángel (1966): "Programa de Ordenamiento y Transformación en la Dirección General de Institutos Penales, año 1967", en: Revista Penal y Penitenciaria $\left(\mathrm{n}^{\circ} 27\right)$, pp. 5-62.

RAMÍREZ, Amelia (2011): "Thomas Hobbes. El carácter pasional de lo humano: la primacía de lo individual y la dimensión subjetiva del "considerar", en: In Itinere. Revista Digital de Estudios Humanísticos de la Universidad FASTA ( $\left.{ }^{\circ} 1\right)$, pp. 21-33. 
ROUSSEAU, Jean Jacques (1999): Del Contrato social (Madrid: Boreal).

RUIZ FUNES, M. (1949): La crisis de la prisión (La Habana: Montero).

RUIZ-MORALES, Manuel Luis (2018): "La evolución de la población reclusa española en los últimos treinta años: una explicación integral”, en: Anuario de Derecho Penal y Ciencias Penales ( $\left.n^{\circ} 71\right)$, pp. 403-490.

RUSCHE, Georg; KIRCHHEIMER, Otto (1984): Pena y estructura social (Bogotá: Temis).

SAINATO, Michael (2019): “¿Por qué mueren tantos presos en Estados Unidos?”, en: eldiario.es (2/06/2019). Disponible en: https://www.eldiario.es/theguardian/muerte-gente-carcelesEEUU_0_905009932.html [visitado el 01/02/2020].

SALILLAS, Rafael (1888): La vida penal en España (Madrid: Imprenta de la Revista de Legislación).

SUTHERLAND, Edwin (1947): Principles of Criminology (Philadelphia: Lippincott).

TÉLLEZ AGUILERA, Abel (1996): "La crisis de la prisión: aproximación práctica a las nuevas fórmulas penológicas", en: Anuario de la Facultad de Derecho de la Universidad de Alcalá (n ${ }^{\circ}$ 6), pp. 99-136.

TÉLLEZ AGUILERA, Abel (1999): "Retos del siglo XXI para el sistema penitenciario español”, en: Anuario de Derecho Penal y Ciencias Penales (Tomo 52), pp. 323338.

TINEDO FERNÁNDEZ, Gladys (2008): "Reflexiones sobre el sentido de la pena", en: Capítulo Criminológico (Vol. 36, nº 4), pp. 27-50.

TOMÁS Y VALIENTE, Francisco (1973): La tortura en España (Barcelona: Ariel).

VON HENTIG, Hans (1969): La pena II. Las formas modernas de aparición (Madrid: Espasa-Calpe).

WACQUANT, Loïc (1999): "Crime e castigo nos Estados Unidos: de Nixon a Clinton", en: Revista de Sociología e Política (n 13$)$, pp. 39-50.

WACQUANT, Loïc (2006): "Castigar a los parias urbanos", en: Antípoda, Revista de Antropología y Arqueología ( $\mathrm{n}^{\circ}$ 2), pp. 59-66.

ZAFFARONI, Eugenio Raúl (1997): "La Filosofía del Sistema Penitenciario en el Mundo Contemporáneo", en: Themis ( $\left.n^{\circ} 35\right)$, pp. 179-191.

ZULETA, Gabriela (2011): “Ganador del concurso para la Prisión Danesa en Falster", en: Plataforma Arquitectura (16/01/2011). Disponible en: http://www.plataformaarquitectura.cl/cl/02-69746/ganador-del-concurso-para-laprision-danesa-en-falster-c-f-m\%25c3\%25b81ler. [visitado el 30.01.2019].

\section{Anexos}

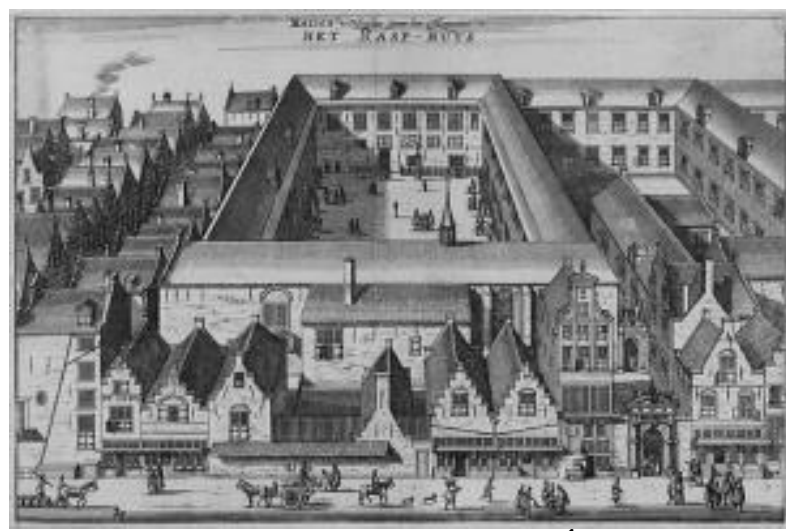

Figura 1. Prisión de Rasphuis, Ámsterdam. 

maneras de comprender la pena de prisión en la historia".

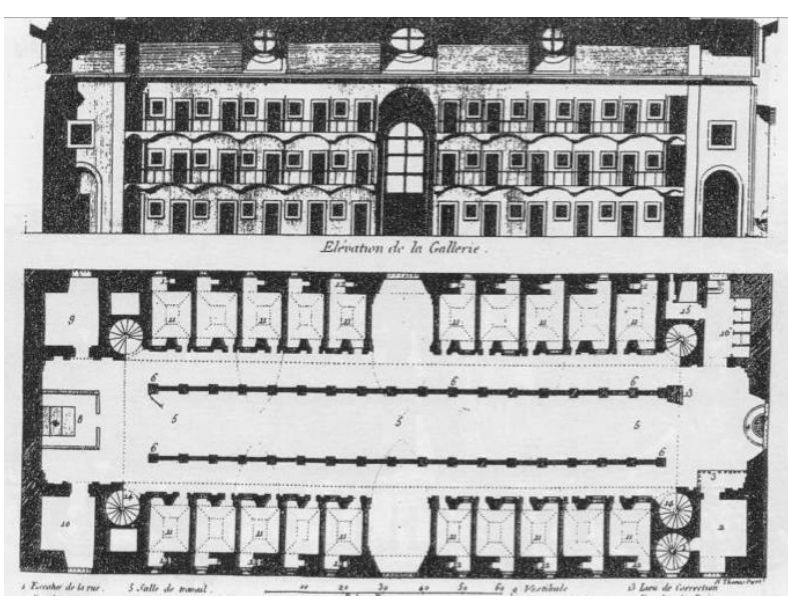

Figura 2. Casa de Corrección San Miguel, Roma.

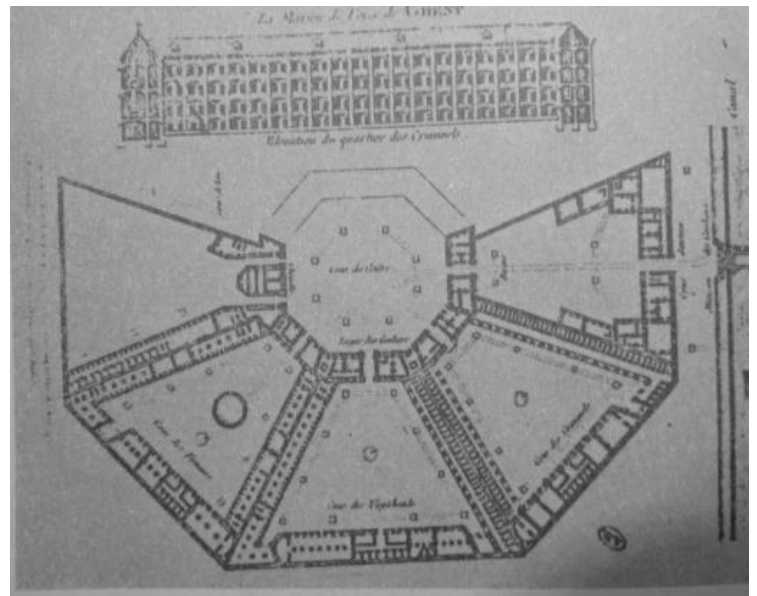

Figura 3. Plano de la Galera de Gante.

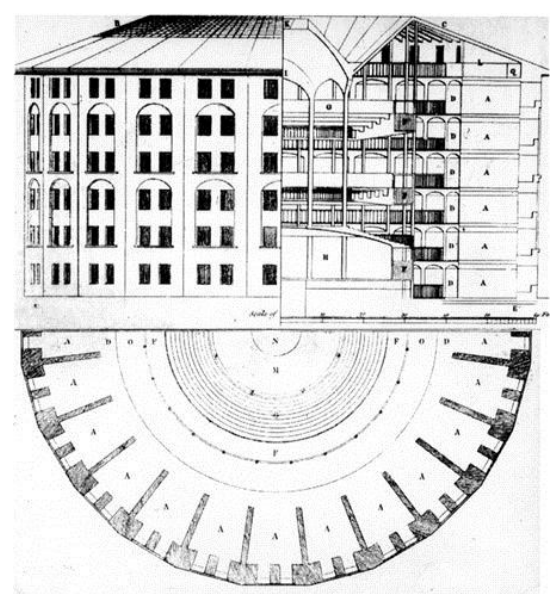

Figura 4. El Panóptico de Bentham. 

maneras de comprender la pena de prisión en la historia".

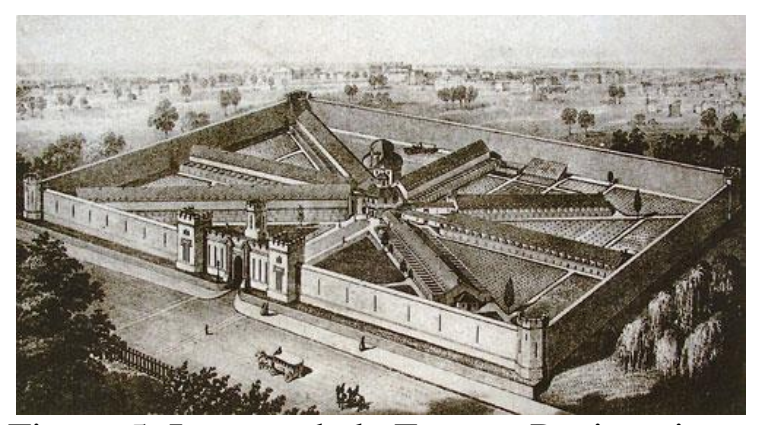

Figura 5. Imagen de la Eastern Penitenciary.

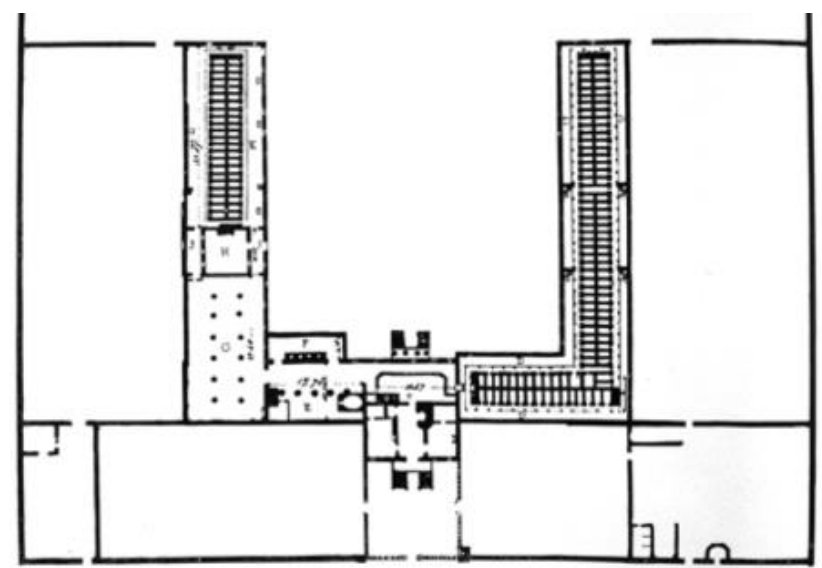

Figura 6. Plano de la Penitenciaría de Auburn.

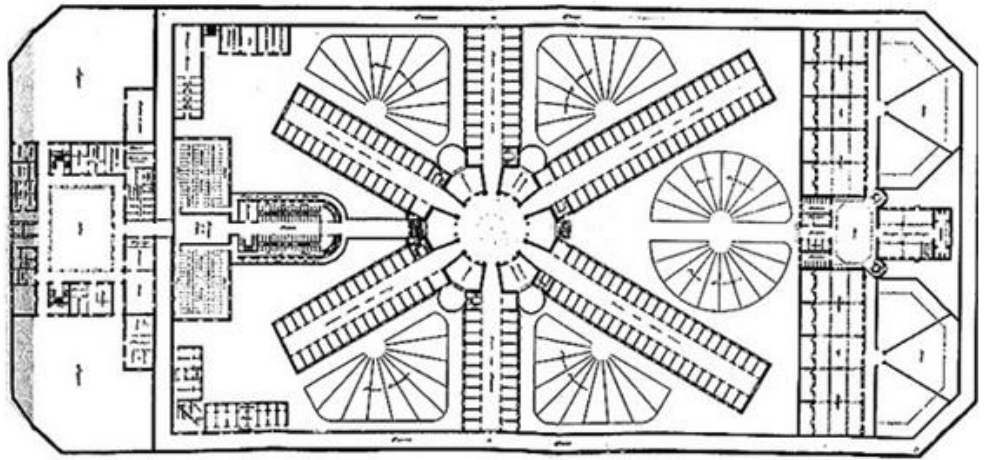

Figura 7. Plano de la Cárcel Modelo de Barcelona.

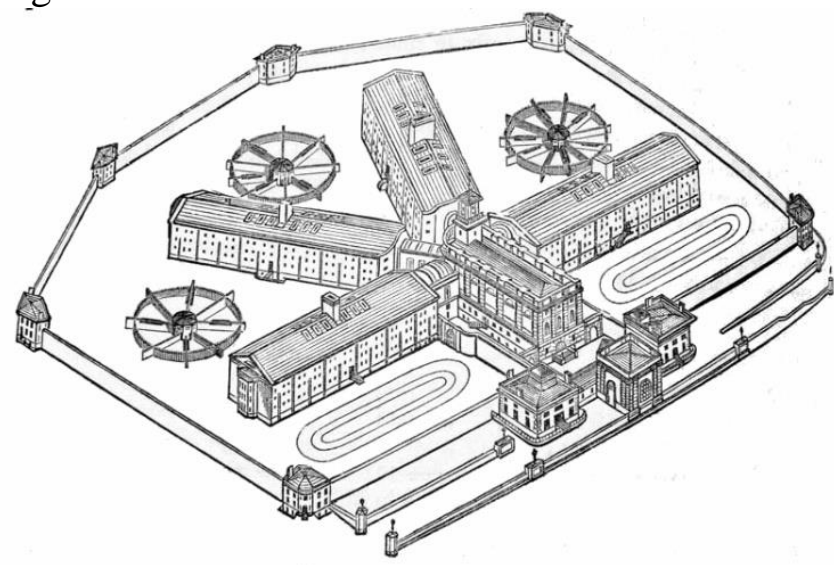

Figura 8. Prisión de Pentonville. 


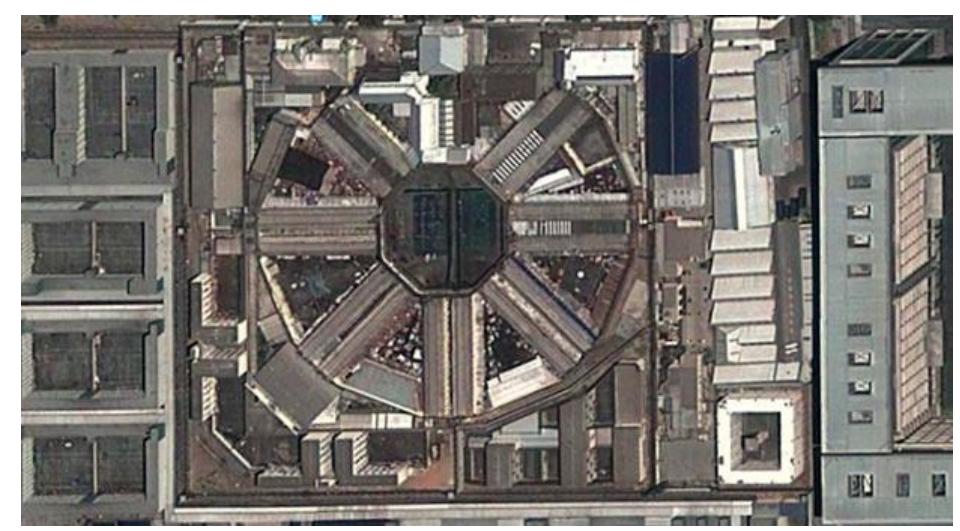

Figura 9. Antigua Penitenciaría de Santiago.

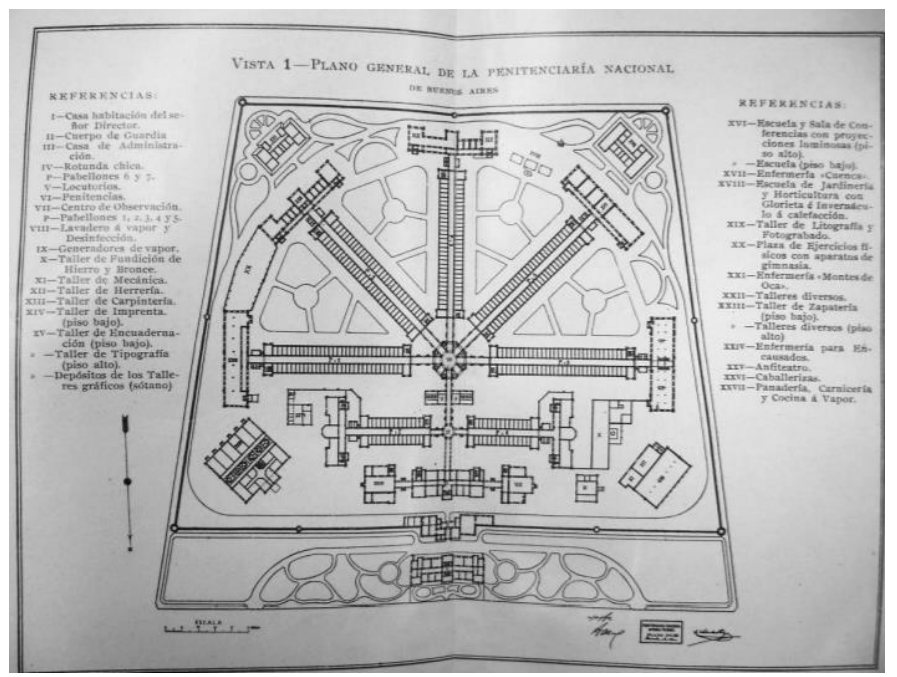

Figura 10. Plano de la Penitenciaría Nacional -Buenos Aires-.

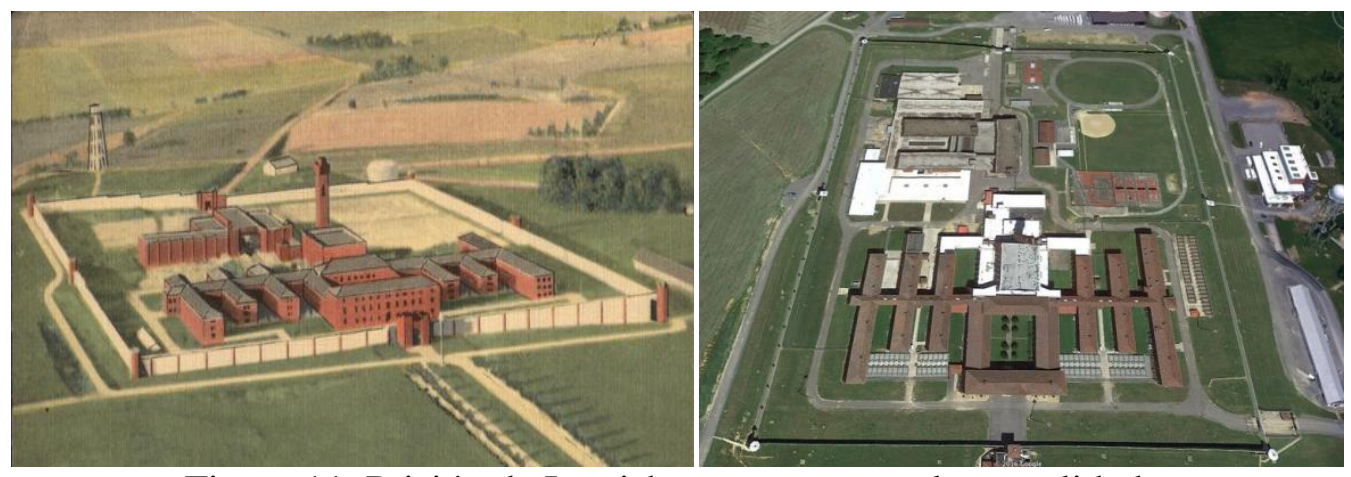

Figura 11. Prisión de Lewisburg -antes y en la actualidad-. 
RUIZ, Manuel: "La arquitectura penitenciaria como representación del castigo. Las maneras de comprender la pena de prisión en la historia".

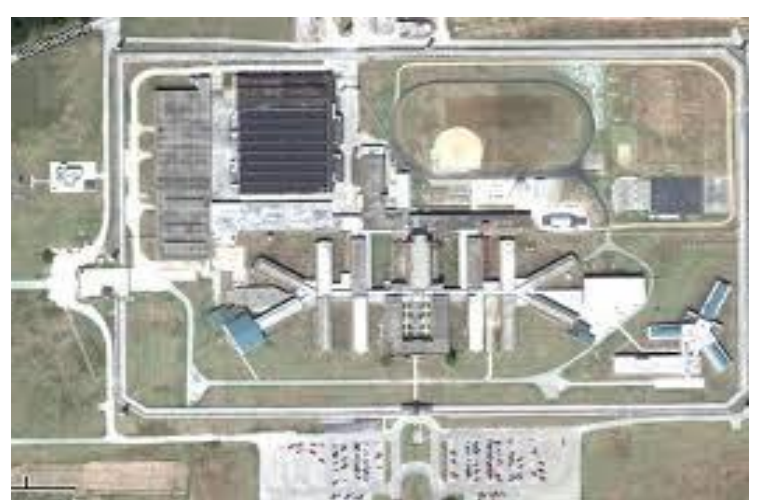

Figura 12. Vista de la Penitenciaría Federal de Indiana.

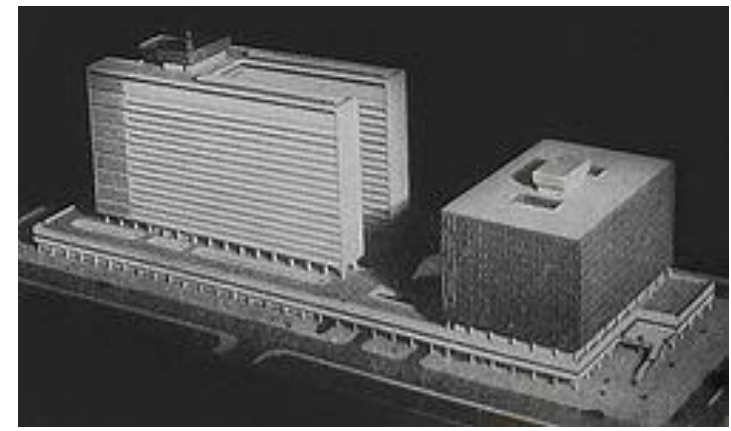

Figura 13. Prototipo de la Cárcel de Caseros "Nueva".

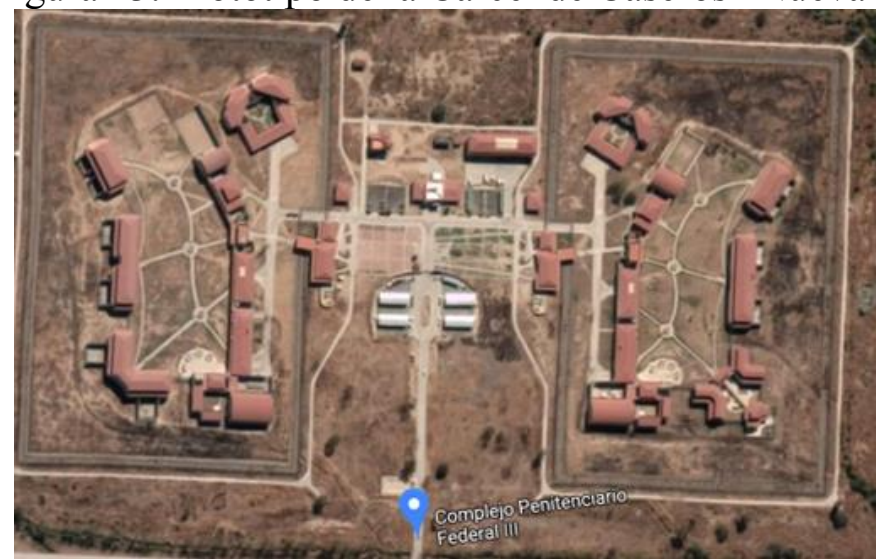

Figura 14. Centro Penitenciario Federal III.

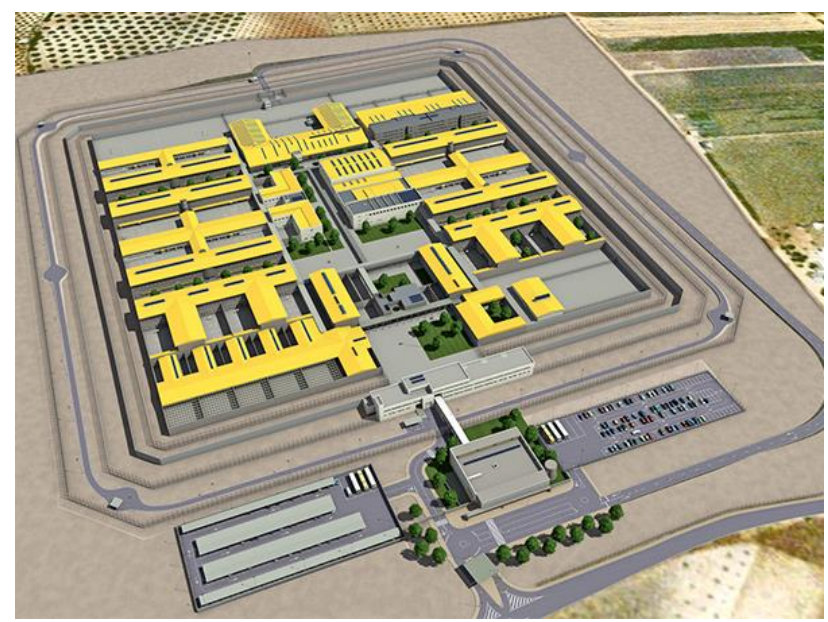


RUIZ, Manuel: “La arquitectura penitenciaria como representación del castigo. Las maneras de comprender la pena de prisión en la historia”.

Figura 15. Diseño del Centro Penitenciario Tipo.

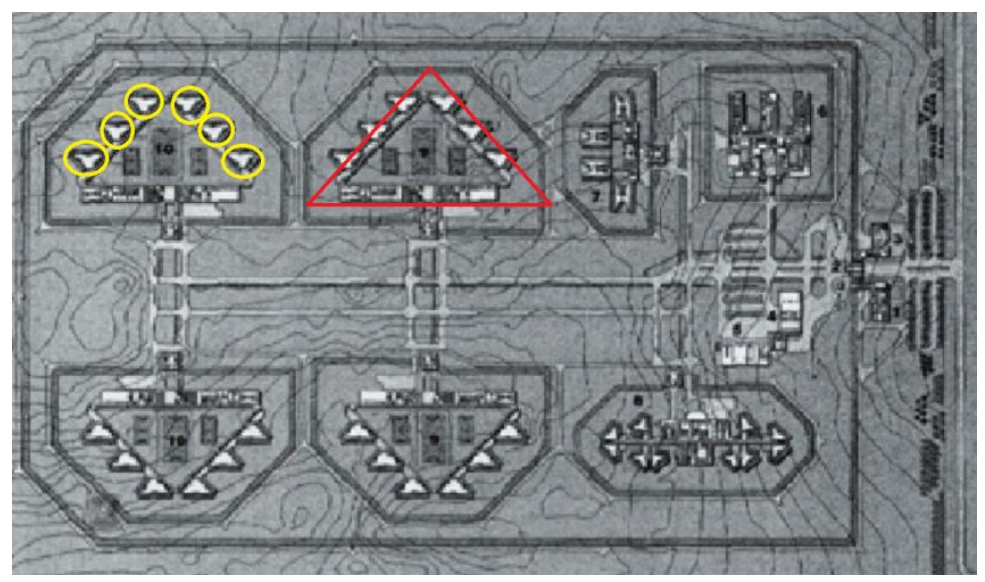

Figura 16. Complejo Penitenciario de Ezeiza

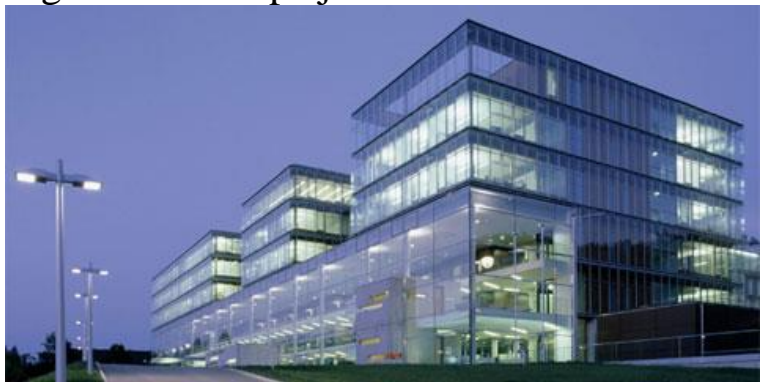

Figura 17. Exterior de la Prisión de Leoben.

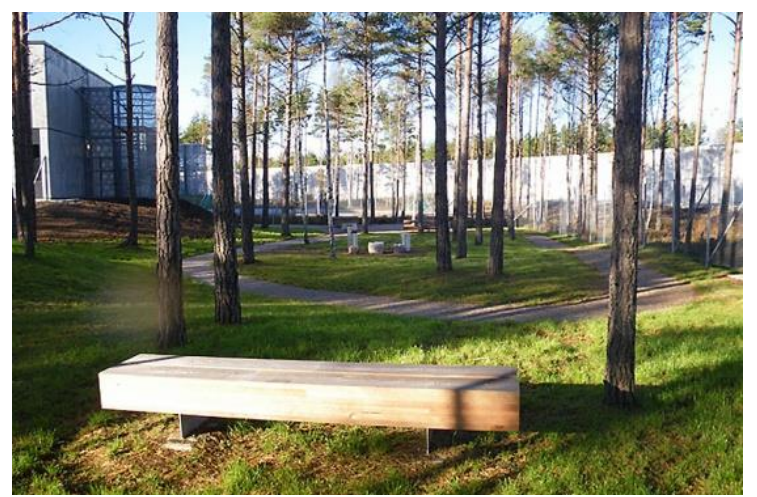

Figura 18. Vegetación en Handel Fengsel. 

maneras de comprender la pena de prisión en la historia".

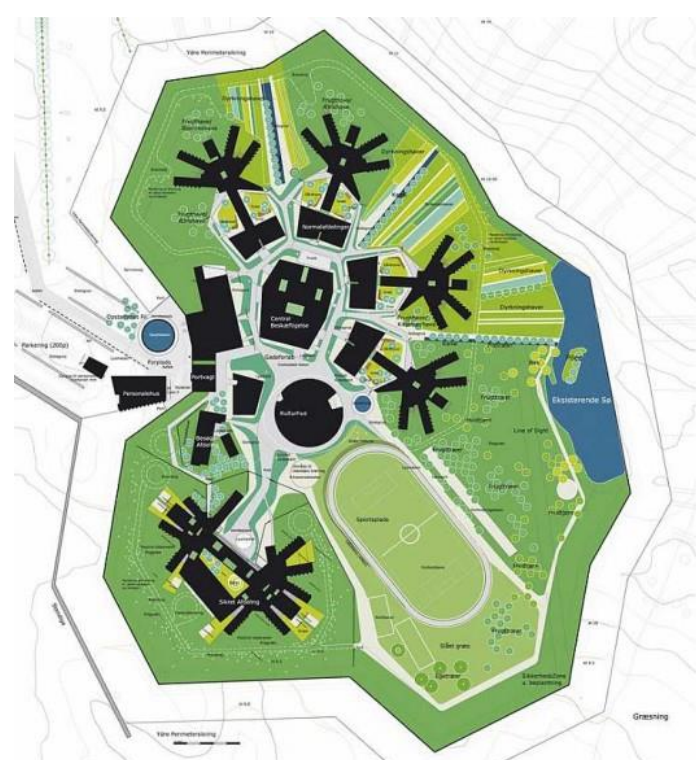

Figura 19. Plano de la cárcel de Storstrøm.

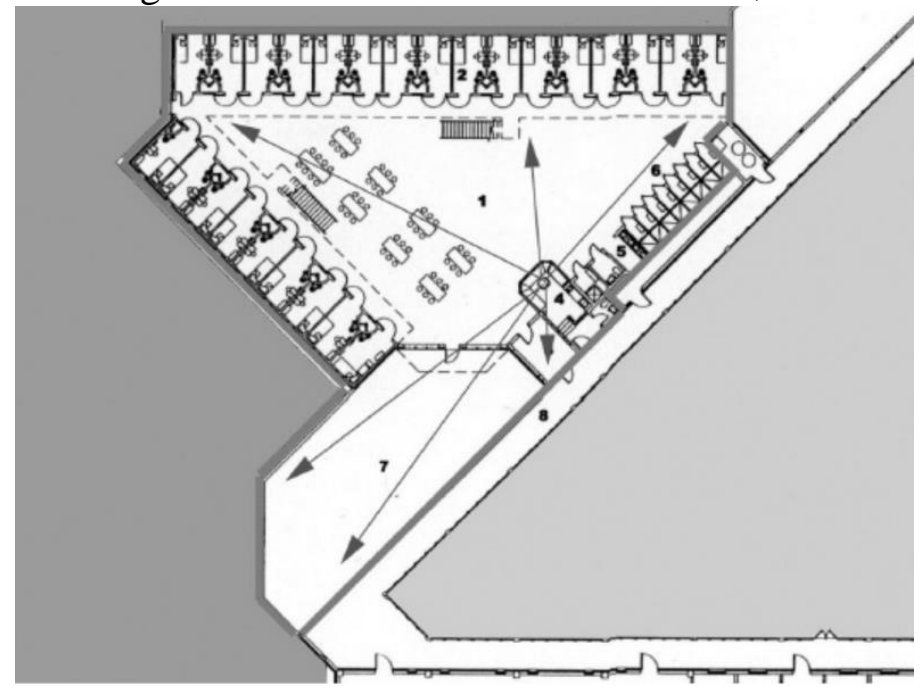

Figura 20. Plano de un sector residencial del Complejo Penitenciario de Ezeiza, dotado de Diseño Podular-Observación Remota-.

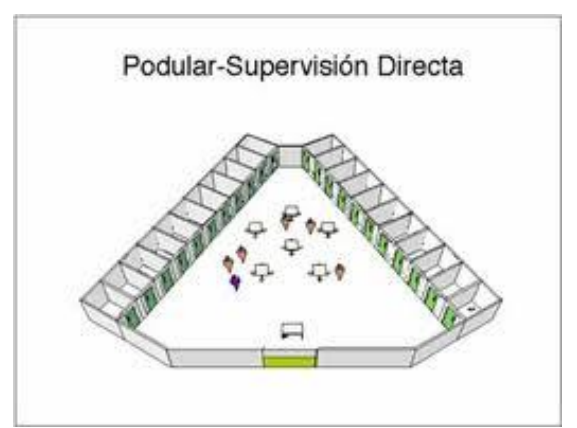

Figura 21. Diseño Podular en su modalidad de Supervisión Directa. 
RUIZ, Manuel: "La arquitectura penitenciaria como representación del castigo. Las maneras de comprender la pena de prisión en la historia".

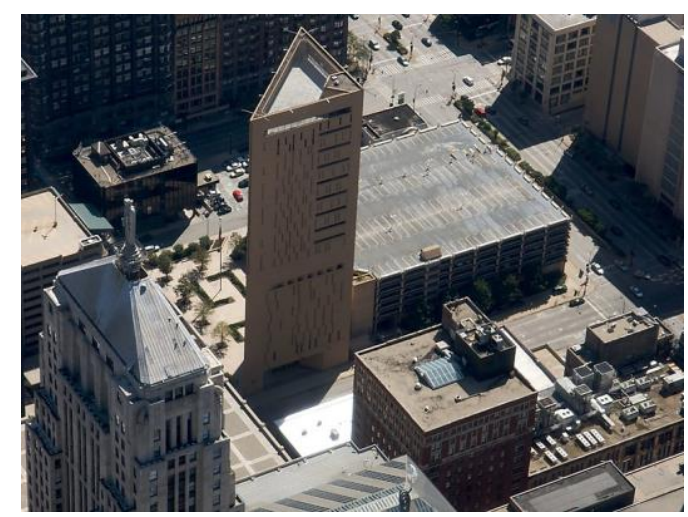

Figura 22. Centro Correccional Metropolitano de Chicago.

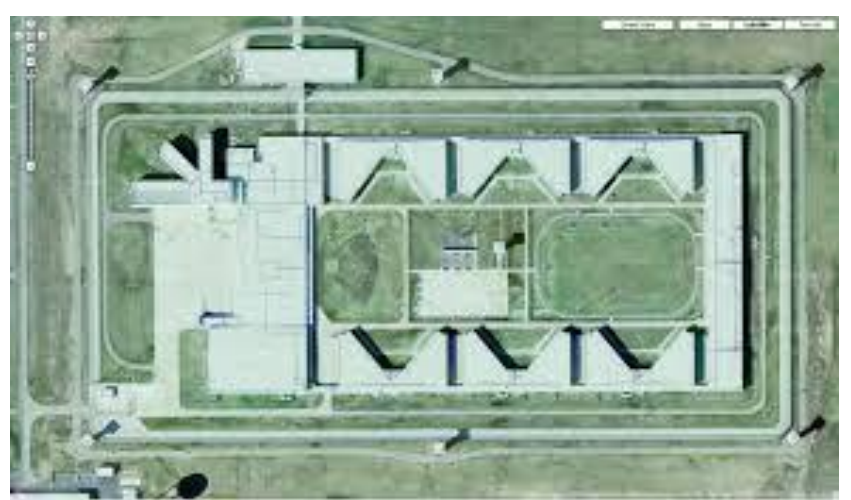

Figura 23. Vista aérea de la Penitenciaría de Terre Haute. 